\title{
Geographic Variations in Arthritis Prevalence, Health-Related Characteristics, and Management — United States, 2015
}




\section{CONTENTS}

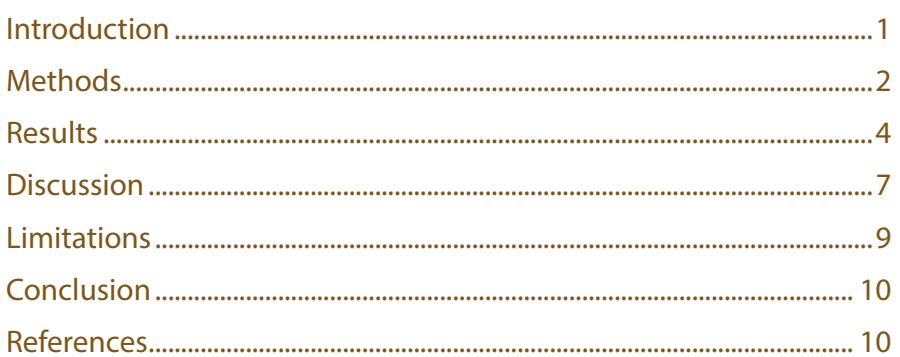

The MMWR series of publications is published by the Center for Surveillance, Epidemiology, and Laboratory Services, Centers for Disease Control and Prevention (CDC), U.S. Department of Health and Human Services, Atlanta, GA 30329-4027.

Suggested citation: [Author names; first three, then et al., if more than six.] [Title]. MMWR Surveill Summ 2018;67(No. SS-\#):[inclusive page numbers].

\section{Centers for Disease Control and Prevention \\ Anne Schuchat, MD, Acting Director \\ Stephen C. Redd, MD, Acting Principal Deputy Director \\ Leslie Dauphin, PhD, Acting Associate Director for Science \\ Joanne Cono, MD, ScM, Director, Office of Science Quality}

Chesley L. Richards, MD, MPH, Deputy Director for Public Health Scientific Services

Michael F. Iademarco, MD, MPH, Director, Center for Surveillance, Epidemiology, and Laboratory Services

\section{MMWR Editorial and Production Staff (Serials)}

Charlotte K. Kent, PhD, MPH, Acting Editor-in-Chief, Executive Editor Christine G. Casey, MD, Editor

Mary Dott, MD, MPH, Online Editor

Teresa F. Rutledge, Managing Editor

David C. Johnson, Lead Technical Writer-Editor

Marella Meadows, Project Editor

Timothy F. Jones, MD, Chairman

Matthew L. Boulton, MD, MPH

Virginia A. Caine, MD

Katherine Lyon Daniel, PhD

Jonathan E. Fielding, MD, MPH, MBA

David W. Fleming, MD

Martha F. Boyd, Lead Visual Information Specialist Maureen A. Leahy, Julia C. Martinroe, Stephen R. Spriggs, Tong Yang, Visual Information Specialists

Quang M. Doan, MBA, Phyllis H. King,

Paul D. Maitland, Terraye M. Starr, Moua Yang, Information Technology Specialists

\section{MMWR Editorial Board}

William E. Halperin, MD, DrPH, MPH

King K. Holmes, MD, PhD

Robin Ikeda, MD, MPH

Rima F. Khabbaz, MD

Phyllis Meadows, $\mathrm{PhD}, \mathrm{MSN}$, RN

Jewel Mullen, MD, MPH, MPA
Jeff Niederdeppe, $\mathrm{PhD}$

Patricia Quinlisk, MD, MPH

Patrick L. Remington, MD, MPH Carlos Roig, MS, MA

William L. Roper, MD, MPH

William Schaffner, MD 


\title{
Geographic Variations in Arthritis Prevalence, Health-Related Characteristics, and Management — United States, 2015
}

\author{
Kamil E. Barbour, $\mathrm{PhD}^{1}$ \\ Susan Moss, $\mathrm{MS}^{2}$ \\ Janet B. Croft, $\mathrm{PhD}^{1}$ \\ Charles G. Helmick, MD ${ }^{1}$ \\ Kristina A. Theis, $\mathrm{PhD}^{1}$ \\ Teresa J. Brady, $\mathrm{PhD}^{1}$ \\ Louise B. Murphy, $\mathrm{PhD}^{1}$ \\ Jennifer M. Hootman, $\mathrm{PhD}^{1}$ \\ Kurt J. Greenlund, $\mathrm{PhD}^{1}$ \\ Hua Lu, MS ${ }^{1}$ \\ Yan Wang, $\mathrm{PhD}^{1}$ \\ ${ }^{1}$ Division of Population Health, National Center for Chronic Disease Prevention and Health Promotion, CDC, Atlanta, Georgia \\ ${ }^{2} G^{2} S$ Corporation, San Antonio, Texas
}

\begin{abstract}
Problem/Condition: Doctor-diagnosed arthritis is a common chronic condition affecting an estimated 23\% (54 million) of adults in the United States, greatly influencing quality of life and costing approximately $\$ 300$ billion annually. The geographic variations in arthritis prevalence, health-related characteristics, and management among states and territories are unknown. Therefore, public health professionals need to understand arthritis in their areas to target dissemination of evidence-based interventions that reduce arthritis morbidity.
\end{abstract}

Reporting Period: 2015.

Description of System: The Behavioral Risk Factor Surveillance System is an annual, random-digit-dialed landline and cellular telephone survey of noninstitutionalized adults aged $\geq 18$ years residing in the United States. Self-reported data are collected from the 50 states, the District of Columbia, Guam, and Puerto Rico. Unadjusted and age-standardized prevalences of arthritis, arthritis health-related characteristics, and arthritis management were calculated. County-level estimates were calculated using a validated statistical modeling method.

Results: In 2015, in the 50 states and the District of Columbia, median age-standardized prevalence of arthritis was 23.0\% (range: 17.2\%-33.6\%). Modeled prevalence of arthritis varied considerably by county (range: $11.2 \%-42.7 \%$ ). In 13 states that administered the arthritis management module, among adults with arthritis, the age-standardized median percentage of participation in a self-management education course was $14.5 \%$ (range: $9.1 \%-19.0 \%$ ), being told by a health care provider to engage in physical activity or exercise was 58.5\% (range: 52.3\%-61.9\%), and being told to lose weight to manage arthritis symptoms (if overweight or obese) was $44.5 \%$ (range: $35.1 \%-53.2 \%)$. Respondents with arthritis who lived in the quartile of states with the highest prevalences of arthritis had the highest percentages of negative health-related characteristics (i.e., arthritis-attributable activity limitations, arthritis-attributable severe joint pain, and arthritis-attributable social participation restriction; $\geq 14$ physically unhealthy days during the past 30 days; $\geq 14$ mentally unhealthy days during the past 30 days; obesity; and leisure-time physical inactivity) and the lowest percentage of leisure-time walking.

Interpretation: The prevalence, health-related characteristics, and management of arthritis varied substantially across states. The modeled prevalence of arthritis varied considerably by county.

Public Health Action: The findings highlight notable geographic variability in prevalence, health-related characteristics, and management of arthritis. Targeted use of evidence-based interventions that focus on physical activity and self-management education can reduce pain and improve function and quality of life for adults with arthritis and thus might reduce these geographic disparities.

\section{Introduction}

Doctor-diagnosed arthritis is a common chronic condition that affected an estimated 23\% (54 million) of adults in the

Corresponding author: Kamil E. Barbour, Division of Population Health, National Center for Chronic Disease Prevention and Health Promotion, CDC. Telephone: 770-488-5145; E-mail: 1ky1@cdc.gov.
United States during 2013-2015 (1). Prevalence varies across states (2), counties (2), urban and rural communities (3), and census tracts within the largest U.S. cities (https://www.cdc. gov/500cities). The condition limits activities of 24 million adults (1), is associated with severe joint pain among 15 million adults (4), and is projected to affect 78.4 million adults by 2040 (5). In 2013, total national medical care expenditures and 
earnings losses attributable to arthritis were $\$ 303.5$ billion (G). Public health measures focus on increasing physical activity, increasing self-management education, increasing health care provider counseling for physical activity or exercise, and encouraging walking.

Since 2003, CDC has conducted surveillance for arthritis using Behavioral Risk Factor Surveillance System (BRFSS) data (7). The findings in this report can be used by public health professionals to better understand geographic variability in prevalence, health-related characteristics, and management of arthritis between states and territories. Public health professionals can also target evidence-based nonpharmaceutical interventions, such as arthritis self-management education and physical activity, to help decrease the impact of arthritis and perhaps reduce geographic disparities in arthritis health-related characteristics and management.

\section{Methods}

To characterize self-reported doctor-diagnosed arthritis in the United States, Guam, and Puerto Rico, CDC analyzed data from the 2015 BRFSS (Box). First, selected arealevel prevalences were estimated, including prevalences of arthritis among adults aged $\geq 18$ years with selected comorbid conditions (i.e., coronary heart disease, diabetes, and obesity). Percentages of health-related characteristics among adults with arthritis (i.e., general health, leisure-time physical activity, activity limitations, and pain) also were estimated. Second, for 13 states with available data, self-management measures for adults with arthritis were examined. Third, to examine possible clustering of arthritis health-related characteristics linear trends were tested between increasing prevalence of arthritis and increasing percentages of negative health-related characteristics among adults with arthritis at the state level. Detailed arthritis surveillance estimates for states, the District of Columbia, Guam, and Puerto Rico are available online for 2011, 2013, and 2015 (https://www.cdc.gov/arthritis/data_statistics/statedata-list-current.htm), but are unpublished elsewhere.

\section{Data Source and Measurements}

BRFSS is an annual, random-digit-dialed landline and cellular telephone survey of the noninstitutionalized U.S. adult population aged $\geq 18$ years. Self-reported data are collected from the 50 states, the District of Columbia, Guam, and Puerto Rico. In 2015, a total of 441,456 interviews were completed and analyzed for this report. Response rates ranged from $33.9 \%$ to $61.1 \%$ (median: $47.2 \%$ ). The response rate was the number of respondents who completed the survey as a proportion of all eligible and likely eligible persons. Response rates for BRFSS
BOX. Understanding geographic variations in arthritis prevalence, health-related characteristics, and management

Aim 1: Estimate prevalence among adults

- Prevalence of arthritis among adults with comorbid conditions (coronary heart disease, diabetes, and obesity)

- Prevalence of obesity among adults with arthritis

- Prevalence of leisure-time walking among adults with arthritis

- Prevalence of physical inactivity among adults with arthritis

- Prevalence of two types of negative health-related characteristics among adults with arthritis: general health (physically and mentally unhealthy days) and arthritis-attributable impact (activity limitations, severe joint pain, and social participation restriction)

Aim 2: Estimate management among adults with arthritis

- Prevalence of participation in arthritis selfmanagement education course

- Prevalence of health care provider counseling for weight loss

- Prevalence of health care provider counseling for physical activity or exercise

Aim 3: Examine possible state-specific clustering of health-related characteristics among adults with arthritis

were calculated using standards set by American Association for Public Opinion Research response rate formula no. 4. Additional information is available at https://www.cdc.gov/ brfss/annual_data/2015/2015_responserates.html.

Respondents were classified as having doctor-diagnosed arthritis (hereafter referred to as arthritis) if they answered yes to the question "Has a doctor, nurse, or other health professional ever told you that you have some form of arthritis, rheumatoid arthritis, gout, lupus, or fibromyalgia?" Three comorbid conditions were examined: obesity, diabetes, and coronary heart disease. Body mass index (BMI) was computed from self-reported height and weight. Obesity was categorized as BMI $\geq 30 \mathrm{~kg} / \mathrm{m}^{2}$. Doctor-diagnosed diabetes (hereafter referred to as diabetes) was defined as a yes response to the question "Has a doctor, nurse, or other health professional ever told you that you have diabetes?" Those with prediabetes or borderline diabetes and women who had diabetes only during pregnancy were classified as not having diabetes. Doctor-diagnosed coronary heart disease (hereafter referred to as coronary heart disease) was defined as a yes response to 
either of the following two questions: 1) "Has a doctor, nurse, or other health professional ever told you that you had a heart attack, also called a myocardial infarction?" or 2) "Has a doctor, nurse, or other health professional ever told you that you had angina or coronary heart disease?"

\section{Prevalence of Arthritis}

The prevalence of arthritis was estimated among all adults. Prevalence was estimated separately for adults with comorbid conditions (i.e., obesity, coronary heart disease, and diabetes).

\section{Health-Related Characteristics}

General Health. Two measures of health-related quality of life were examined. For physically and mentally unhealthy days, respondents reported the number of days during the past 30 days that their physical or mental health, or both, was not good. For each measure, a standard predetermined cutoff point of $\geq 14$ days during the past 30 days was used to identify respondents with poor physical or mental health, respectively (8).

Leisure-Time Physical Activity and Obesity. Among adults with arthritis, the prevalences of obesity, leisure-time physical inactivity, and leisure-time walking were estimated. Leisuretime physical inactivity was defined as a no response to the question "During the past month, other than your regular job, did you participate in any physical activities or exercises such as running, calisthenics, golf, gardening, or walking for exercise?" Among those who answered yes, leisure-time walking was ascertained via two questions: 1) "What type of physical activity or exercise did you spend the most time doing during the past month?" and 2) "What other type of physical activity gave you the next most exercise during the past month?" For the leisure-time walking measure, the numerator was adults with arthritis who listed walking as one of their top two activities and the denominator included both active and inactive adults with arthritis.

Activity Limitations. Among adults with arthritis, arthritisattributable activity limitations were identified by a yes response to the question "Are you now limited in any way in any of your usual activities because of arthritis or joint symptoms?" Arthritis-attributable social participation restriction was defined as a response of a lot to the question "During the past 30 days, to what extent has your arthritis or joint symptoms interfered with your normal social activities, such as going shopping, to the movies, or to religious or social gatherings?"

Pain. Arthritis-attributable severe joint pain was defined according to an a priori criterion (9) as a pain level of $7-10$ on a scale of $0-10$ where 0 is no pain and 10 is pain or aching as bad as it can be for the question "Please think about the past 30 days, keeping in mind all of your joint pain or aching and whether or not you have taken medication. During the past 30 days, how bad was your joint pain on average?"

\section{Arthritis Management}

In 2015, a total of 13 states (California, Kansas, Kentucky, Michigan, Minnesota, Missouri, Montana, New York, Oregon, Pennsylvania, Rhode Island, South Carolina, and Utah) administered the BRFSS arthritis management module to respondents with arthritis and ascertained participation in self-management education courses and receipt of health care provider counseling. Among adults with arthritis, attendance at a self-management education course was defined as a yes response to the question "Have you ever taken an educational course or class to teach you how to manage problems related to your arthritis or joint symptoms?" Among those who were overweight (BMI 25 to $<30 \mathrm{~kg} / \mathrm{m}^{2}$ ) or obese $\left(\mathrm{BMI} \geq 30 \mathrm{~kg} / \mathrm{m}^{2}\right.$ ), health care provider counseling for weight loss was defined as a yes response to the question "Has a doctor or other health professional ever suggested losing weight to help your arthritis or joint symptoms?" Health care provider counseling for physical activity or exercise was defined as a yes response to the question "Has a doctor or other health professional ever suggested physical activity or exercise to help your arthritis or joint symptoms?"

\section{Analyses}

\section{Direct Estimates}

All directly estimated analyses included adjustment for the complex survey design; sampling weights accounted for nonresponse, noncoverage, and cellular-telephone-only households and were derived from an iterative proportional weighting (raking) procedure (https://www.cdc.gov/brfss/ annual_data/2015/pdf/weighting_the-data_webpage_content. pdf). Estimates were age standardized to the 2000 U.S. projected population using three age groups ( $18-44,45-64$, and $\geq 65$ years) (10). Weighted unadjusted and age-standardized prevalences with $95 \%$ confidence intervals were estimated for arthritis and arthritis-related characteristics. For each characteristic, the median and range were calculated using prevalence estimates for the 50 states and the District of Columbia (not including Guam and Puerto Rico). The unadjusted prevalence is an estimate of the actual prevalence of a characteristic in a specific area. Age-standardized prevalence estimates are provided to permit comparisons across states. Prevalence estimates of arthritis and percentages of selected characteristics among adults with arthritis that had a relative standard error (RSE) $\geq 30 \%$ or unweighted sample size of $<50$ did not meet the minimum criteria for precision and were suppressed. 


\section{Indirect (Modeled) County-Level Arthritis Prevalence Estimates}

Prevalence of arthritis at the county level was estimated with a multilevel regression model and poststratification approach (11) for counties $(\mathrm{N}=3,142)$ in all 50 states and the District of Columbia. The multilevel regression model included individual-level data on age group (13 categories), sex, and race/ethnicity from the 2015 BRFSS; county-level poverty data (percentage below $150 \%$ of the federal poverty level) from the American Community Survey 5-year estimates (2011-2015) (12); and random effects at county and state levels. Parameter estimates from the models were applied to Census Vintage 2015 county population estimates to generate county-level estimates of arthritis prevalence. These modeled prevalence estimates were reported in quartiles for the 3,142 counties. High internal validity was established by comparing modeled county-level estimates of arthritis with actual unweighted BRFSS survey estimates in 1,531 counties with $\geq 50$ respondents and RSE $<30 \%$ (Pearson correlation coefficient: 0.78; $\mathrm{p}<0.001)$ and with weighted BRFSS estimates in 205 counties with $\geq 500$ respondents (Pearson correlation coefficient: 0.94; $\mathrm{p}<0.001$ ).

\section{State-Specific Clustering of Health-Related Characteristics}

States and the District of Columbia were divided into quartiles (lowest to highest) according to age-adjusted state-level prevalence of arthritis in 2015. Age-standardized percentages of seven negative health-related characteristics among adults with arthritis (i.e., arthritis-attributable activity limitations, arthritis-attributable severe joint pain, and arthritis-attributable social participation restriction; $\geq 14$ physically unhealthy days; $\geq 14$ mentally unhealthy days; obesity; and leisure-time physical inactivity) and leisure-time walking were calculated for respondents by quartile of arthritis prevalence. A test of trend using orthogonal polynomial contrasts (by partitioning the sums of squares) was performed to determine whether the age-standardized prevalence of negative health-related characteristics increased and leisure-time walking decreased among adults with arthritis living in states with greater agestandardized prevalence of arthritis. To improve data fit and accommodate nonlinear trends, the test for trend included a quadratic term. For each health-related characteristic, a statistically significant trend in age-standardized percentage across arthritis quartiles was determined at the Bonferronicorrected alpha level of $0.006(\alpha=0.05 / 8)$ to adjust for testing multiple characteristics.

\section{Results}

\section{Arthritis Prevalence}

In 2015, for the 50 states and the District of Columbia, agestandardized median prevalence of arthritis was $23.0 \%$ (range: $17.2 \%$ in Hawaii to $33.6 \%$ in West Virginia) (Table 1). The model-based prevalence estimates of arthritis across the 3,142 U.S. counties in 50 states and the District of Columbia ranged from $11.2 \%$ to $42.7 \%$ (Figure 1 ). At the county level, counties in Appalachia and along the lower Mississippi River tended to have higher predicted prevalences of arthritis. The majority of counties in Alabama, Arkansas, Kentucky, Michigan, Missouri, Tennessee, and West Virginia were in the highest quartile (31.2\%-42.7\%).

\section{Arthritis Among Adults With Comorbid Conditions}

For the 50 states and District of Columbia, the median agestandardized prevalence of arthritis among adults with obesity was $30.9 \%$ (range: $24.6 \%$ in Texas to $41.2 \%$ in West Virginia) (Table 2). The median age-standardized prevalence of arthritis among adults with coronary heart disease was $44.5 \%$ (range: $25.6 \%$ in the District of Columbia to $72.6 \%$ in Iowa) (Table 3). The median age-standardized prevalence of arthritis among adults with diabetes was $37.3 \%$ (range: $27.1 \%$ in California to $53.7 \%$ in Maine) (Table 4).

\section{Health-Related Characteristics}

\section{General Health}

In 2015, the percentage of poor health-related quality of life among adults with arthritis varied substantially by state. The median age-standardized percentage of $\geq 14$ physically unhealthy days during the past 30 days was $27.7 \%$ (range: $16.9 \%$ in Alaska to $37.5 \%$ in Oklahoma) (Table 5). The median age-standardized percentage of $\geq 14$ mentally unhealthy days during the past 30 days was $22.3 \%$ (range: $14.8 \%$ in Hawaii to $31.1 \%$ Mississippi) (Table 6).

\section{Leisure-Time Physical Activity and Obesity}

In 2015, for leisure-time physical inactivity, the median age-standardized percentage among adults with arthritis was $35.0 \%$ (range: $23.1 \%$ in California to $47.9 \%$ in Mississippi) (Table 7). States in the western United States (e.g., California, Idaho, Oregon, and Washington) tended to have the lowest prevalence of leisure-time physical inactivity among adults with arthritis, whereas states primarily in Appalachia and along the Ohio River and Mississippi River had the highest percentage of leisure-time physical inactivity (Figure 2). Agestandardized percentage of leisure-time physical inactivity was $\geq 40 \%$ in Alabama, Arkansas, Louisiana, Mississippi, 
FIGURE 1. Model-based prevalence* of arthritis ${ }^{\dagger}$ among adults aged $\geq 18$ years, by county - Behavioral Risk Factor Surveillance System, United States, 2015

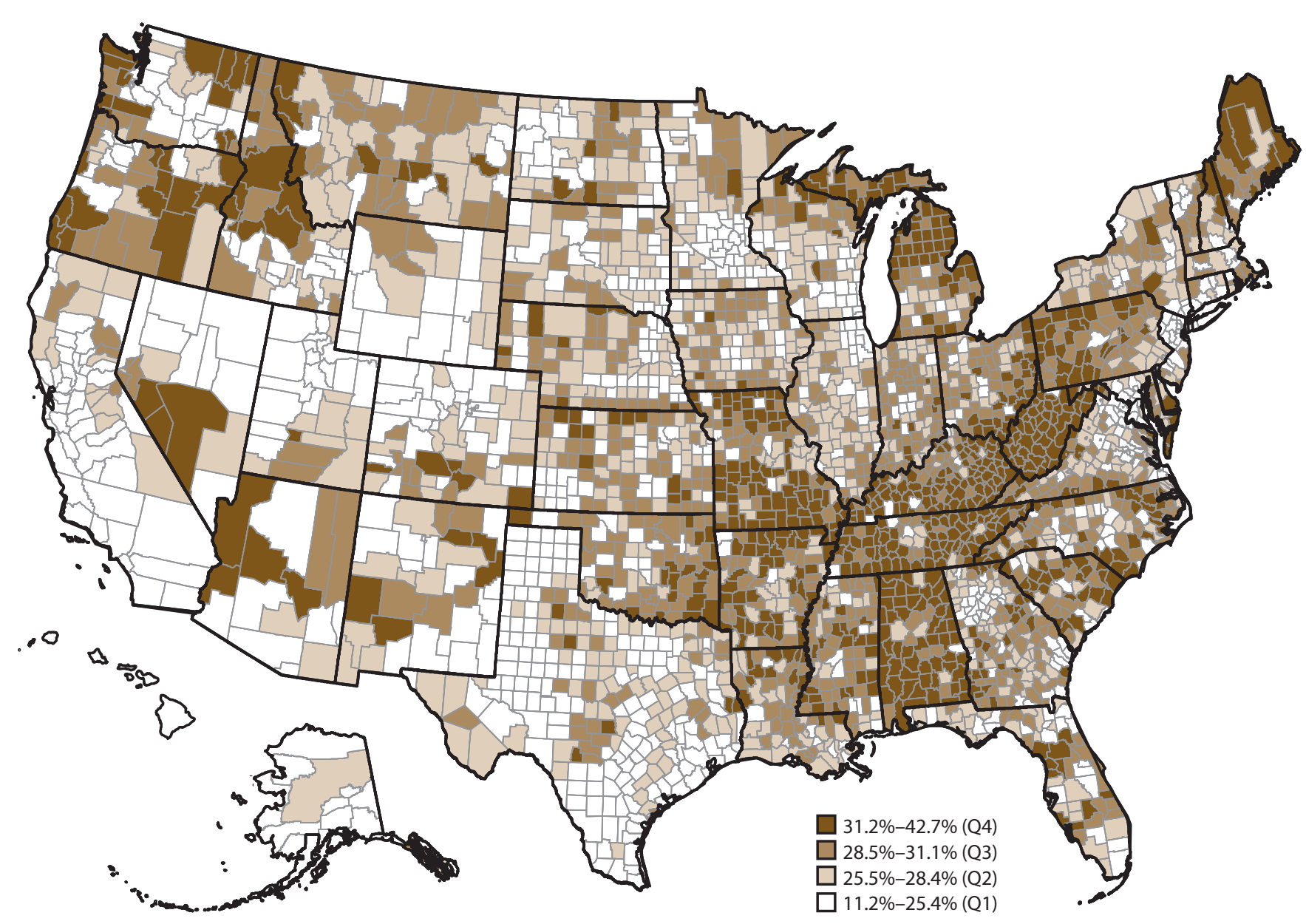

Abbreviation: $\mathrm{Q}=$ quartile.

* Prevalence of arthritis at the county level was estimated with a multilevel regression model and poststratification approach for counties $(\mathrm{N}=3,142)$ in all 50 states and the District of Columbia. Prevalence was based on the Behavioral Risk Factor Surveillance System definition of arthritis.

+ Doctor-diagnosed arthritis was defined as a yes response to the question "Has a doctor, nurse, or other health professional ever told you that you have some form of arthritis, rheumatoid arthritis, gout, lupus, or fibromyalgia?"

Oklahoma, and Texas. For the 50 states and the District of Columbia, the median age-standardized percentage of leisuretime walking was $48.0 \%$ (range: $38.5 \%$ in West Virginia to $59.5 \%$ in Montana) (Table 8). Leisure-time walking tended to be highest in western states (e.g., California, Idaho, Oregon, and Washington) and lowest in states primarily in Appalachia and along the Ohio River and Mississippi River (e.g., Alabama, Arkansas, Mississippi, and West Virginia) (Figure 3).

For the 50 states and the District of Columbia, the percentage of obesity among adults with arthritis varied substantially. The median age-standardized percentage of obesity was $41.6 \%$ (range: $28.1 \%$ in California to $48.9 \%$ in Arkansas) (Table 9).

\section{Activity Limitations}

In 2015, for the 50 states and the District of Columbia, the median age-standardized percentage of arthritis-attributable activity limitations among adults with arthritis was $49.7 \%$ (range: $40.4 \%$ in Iowa to $59.4 \%$ in Missouri) (Table 10). The median age-standardized percentage for arthritis-attributable social participation restriction was $19.7 \%$ (range: $12.6 \%$ in Alaska to $30.4 \%$ in Arkansas) (Table 11).

\section{Pain}

In 2015, the median age-standardized percentage of arthritisattributable severe joint pain among adults with arthritis was $29.7 \%$ (range: $20.3 \%$ in Utah to $46.0 \%$ in Mississippi) (Table 12). States with the highest age-standardized percentage of 
FIGURE 2. Age-standardized prevalence of physical inactivity* among adults aged $\geq 18$ years with arthritis, by state - Behavioral Risk Factor Surveillance System, United States, 2015

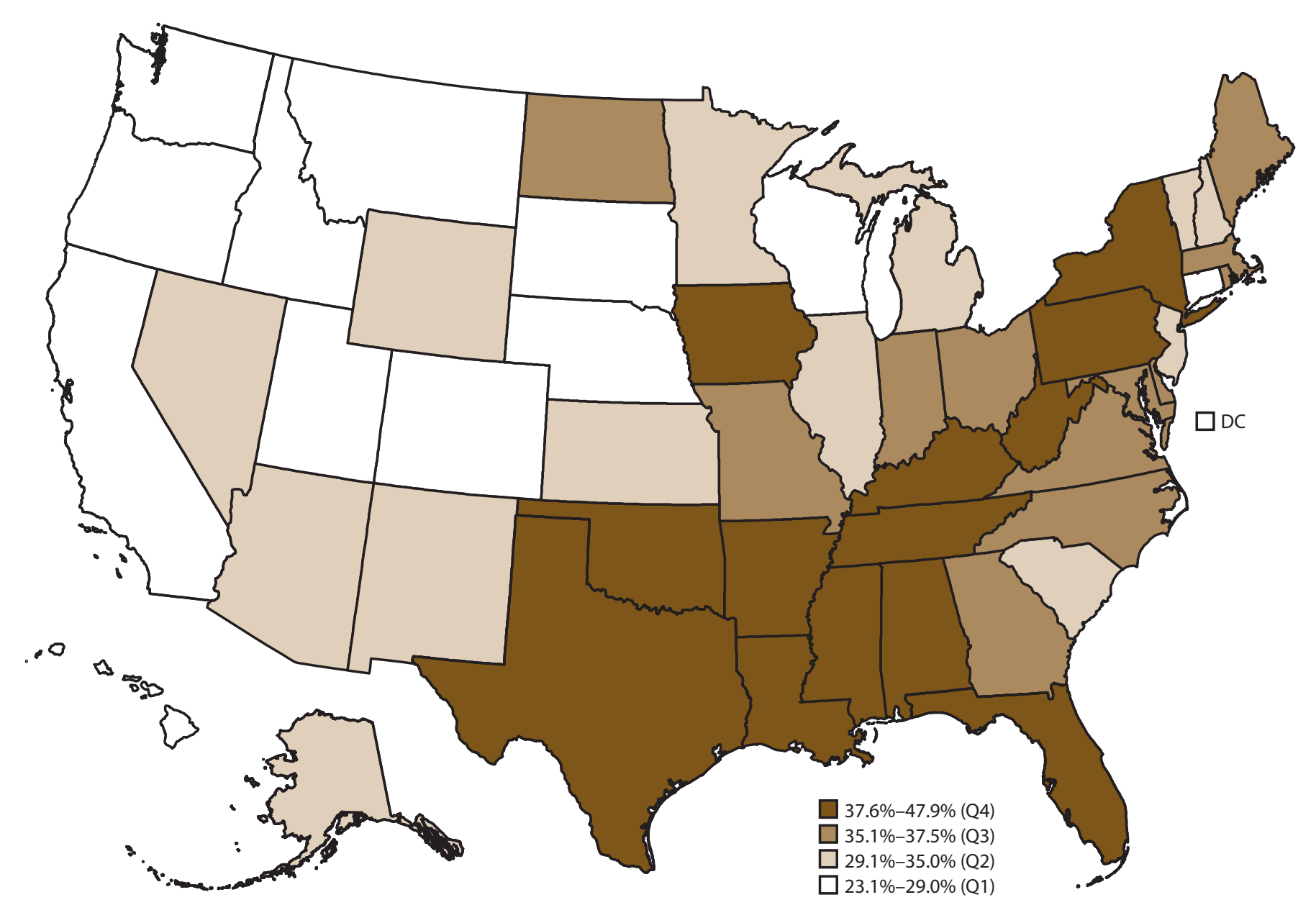

Abbreviations: $\mathrm{DC}=$ District of Columbia; $\mathrm{Q}=$ quartile.

* Physical inactivity was defined as a no response to the question "During the past month, other than your regular job, did you participate in any physical activities or exercises such as running, calisthenics, golf, gardening, or walking for exercise?"

arthritis-attributable severe joint pain among adults with arthritis tended be primarily in Appalachia and in the South (Figure 4).

\section{Arthritis Management}

In 2015, among adults with arthritis in 13 states that included the BRFSS arthritis management module, the age-standardized median percentage of attendance at a selfmanagement education course was 14.5\% (range: $9.1 \%$ in New York to $19.0 \%$ in Montana) (Table 13). The median age-standardized percentage of health care provider counseling to lose weight if overweight or obese was $44.5 \%$ (range: $35.1 \%$ in Montana to $53.2 \%$ in New York) (Table 14). The agestandardized percentage of health care provider counseling for physical activity or exercise did not vary considerably among states (median: 58.5\%; range: 52.3\%-61.9\%) (Table 15).

\section{Possible State-Specific Clustering of Health-Related Characteristics}

States in the highest quartile of prevalence for adults with arthritis also had the highest percentages of all seven negative health-related characteristics (arthritis-attributable activity limitations, severe joint pain, and social participation restriction; $\geq 14$ physically unhealthy days during the past 30 days; $\geq 14$ mentally unhealthy days during the past 30 days; obesity; and leisure-time physical inactivity) and the lowest percentages of leisure-time walking compared with states in the lower quartiles ( $p$-trend $<0.006$ for all characteristics) when both linear and quadratic tests for trends were conducted (Table 16). States in the highest quartile were Maine, Pennsylvania, West Virginia, Kentucky, Tennessee, Arkansas, 
FIGURE 3. Age-standardized prevalence of walking* among adults aged $\geq 18$ years with arthritis, by state - Behavioral Risk Factor Surveillance System, United States, 2015

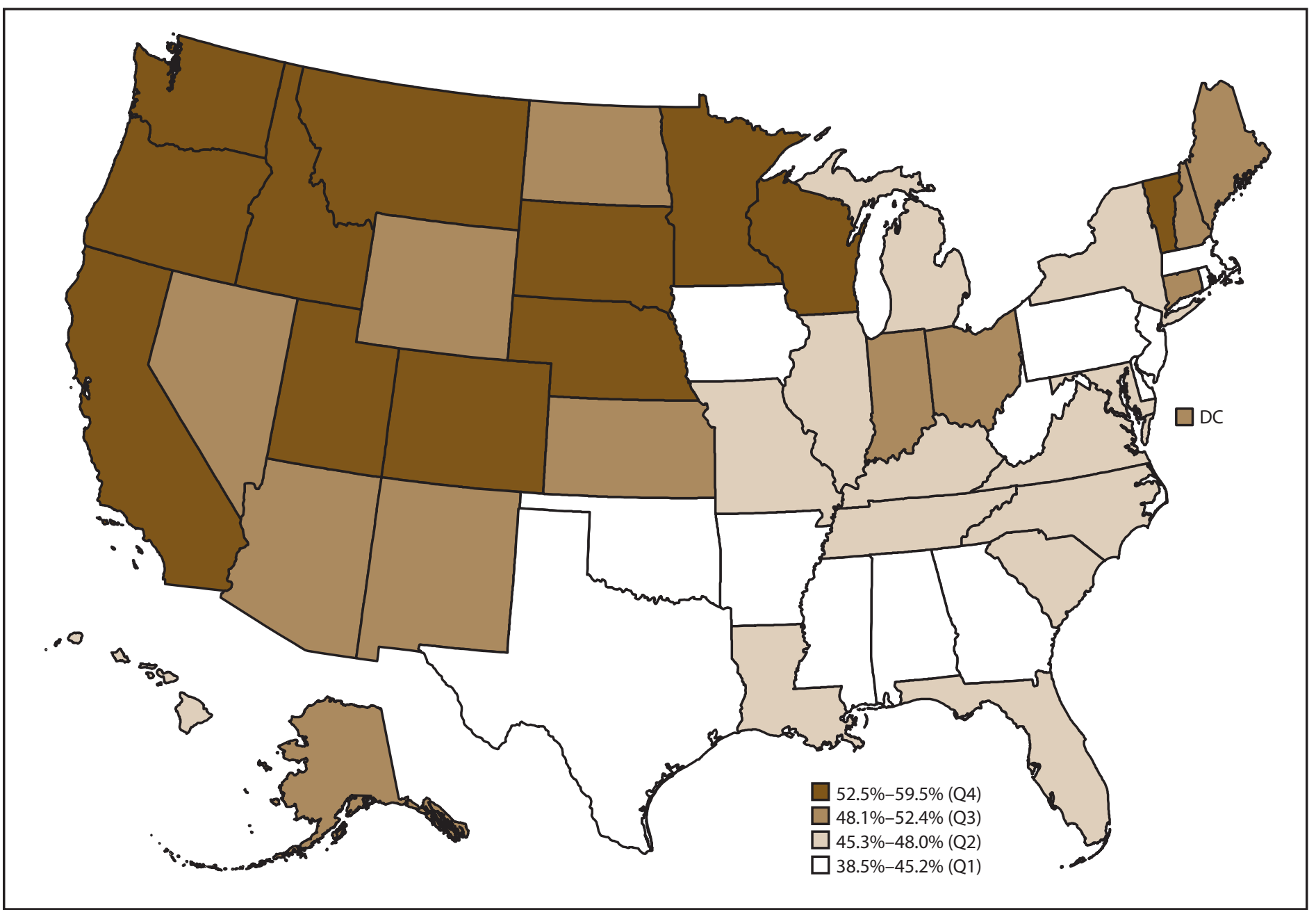

Abbreviations: $\mathrm{DC}=$ District of Columbia; $\mathrm{Q}=$ quartile.

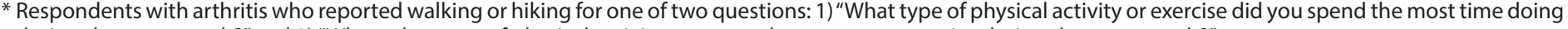
during the past month?" and 2) "What other type of physical activity gave you the next most exercise during the past month?"

Missouri, Oklahoma, Louisiana, Mississippi, Alabama, South Carolina, and Michigan.

\section{Discussion}

This is the first report of state-level arthritis prevalence estimates. The large sample size allowed precise estimates for even limited areas and analysis of health-related characteristics and comorbidities. This report also provides model-based county-level arthritis prevalence estimates with high internal validity, which help improve understanding of arthritis disparities at a local level.

In 2015, arthritis affected approximately one in four adults in the United States overall but prevalence, including model-based estimates at the county level, varied substantially by geographic area. The percentage of negative health-related characteristics among adults with arthritis was high in every area, but also varied substantially by geographic area. Arthritis management measures by state indicated both wide variation (e.g., health care provider counseling to lose weight if overweight or obese) and moderate variation (e.g., individual report of ever attending a self-management course and health care provider counseling for exercise or physical activity). Geographic disparities exist across the United States, with arthritis having the greatest impact in southern states (e.g., West Virginia, Kentucky, Tennessee, Arkansas, Missouri, Oklahoma, Louisiana, Mississippi, Alabama, and South Carolina). More detailed estimates for each of the 50 states, the District of Columbia, Guam, and Puerto Rico, along with additional analyses not reported here are available on the CDC Arthritis 
FIGURE 4. Age-standardized prevalence of arthritis-attributable severe joint pain* among adults aged $\geq 18$ years with arthritis, by state ${ }^{\dagger}$ Behavioral Risk Factor Surveillance System, United States, 2015

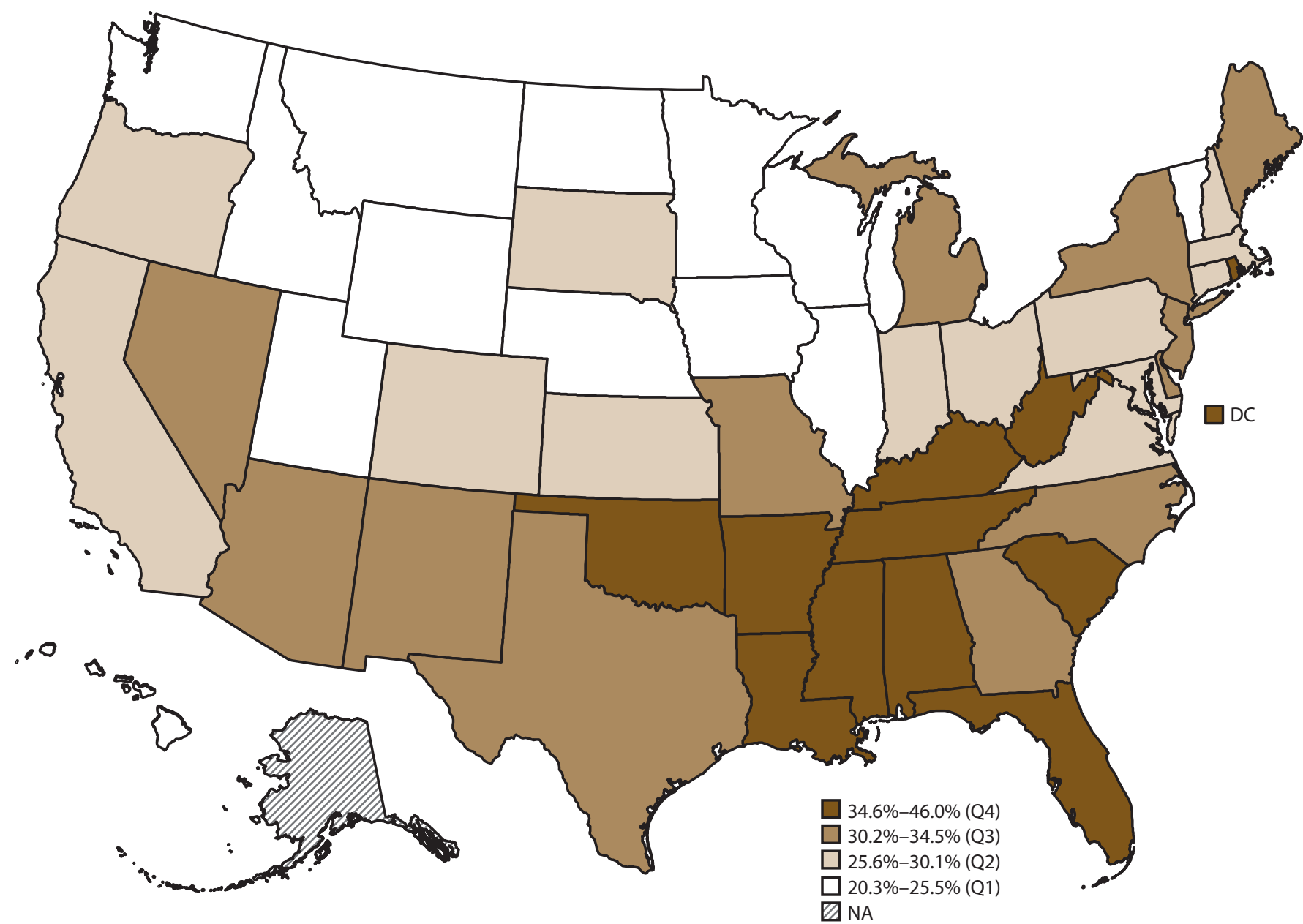

Abbreviations: $\mathrm{DC}=$ District of Columbia; $\mathrm{NA}=$ not applicable; $\mathrm{Q}=$ quartile.

* Respondents with arthritis who answered 7, 8, 9, or 10 to the question "Please think about the past 30 days, keeping in mind all of your joint pain or aching and whether or not you have taken medication. During the past 30 days, how bad was your joint pain on average? Please answer on a scale of 0 to 10 where 0 is no pain or aching and 10 is pain or aching as bad as it can be." Severe joint pain was defined as a pain level of 7-10.

† Estimate for one state (Alaska) with a relative standard error $>30 \%$ or unweighted denominator $<50$ was suppressed as unreliable.

Program website (https://www.cdc.gov/arthritis/data_statistics/ state-data-list-current.htm).

States with greater prevalences of arthritis also had greater percentages of negative health-related characteristics (i.e., arthritis-attributable activity limitations, arthritis-attributable severe joint pain, and arthritis-attributable social participation restriction; $\geq 14$ physically unhealthy days during the past 30 days; $\geq 14$ mentally unhealthy days during the past 30 days; obesity; and physical inactivity) and lesser percentages of leisure-time walking (a recommended management strategy) among adults with arthritis. The reasons for this geographic clustering are unknown but suggest a greater arthritis impact among adults with arthritis who live in those states. Geographic variation in four recognized risk factors for arthritis (i.e., obesity, occupations with high physical workload, smoking, and socioeconomic status) (13-17) that are also associated with negative health consequences among adults with arthritis might account for some of the difference. Geographic variations also might exist in access to medical care, including medications, resources for physical activity, and self-management interventions. Furthermore, because those states also have greater prevalence of coronary heart disease and diabetes, two important comorbid conditions for arthritis, health care providers might focus more on treatment and management of those chronic conditions with less emphasis on treatment and management of arthritis (18).

Adults with arthritis have a complex combination of disease characteristics and negative health consequences that can limit 
their daily activities; reduce health-related quality of life; and contribute to sustained obesity, leisure-time physical inactivity, and lack of participation in leisure-time walking. Participation in self-management education courses among adults with arthritis remains low (19). Only half of patients with arthritis receive counseling on the self-management behaviors of physical activity and weight loss. More counseling might help reduce the proportion with arthritis reporting obesity or leisure-time physical inactivity (approximately two in five adults) (20,21). Greater use of evidence-based interventions for physical activity and self-management education could reduce pain and improve function and quality of life for all adults with arthritis $(22,23)$.

Nationally, approximately one in four adults with arthritis reported severe joint pain in the National Health Interview Survey (4); however, the geographic variations in this report suggest that the prevalence is higher in certain states (four in 10 might experience severe joint pain). Arthritis-attributable severe joint pain can lead to poor physical function. In a cohort of retirees in the United States with arthritis, approximately three in four reported functional limitations and approximately $65 \%$ had mobility limitations (24). Poor physical function is a major risk factor linked to falls (25), and adults with arthritis are more than twice as likely to report fall injuries compared with adults without arthritis (26). In addition to decrements in physical function, adults with arthritis consistently report negative effects on health-related quality of life. One study that examined health-related quality of life measures among adults with and without arthritis found that those with arthritis had higher mean numbers of days in the prior month when physical and mental health were not good (27). In this study, approximately one in four adults with arthritis reported $\geq 14$ physically and $\geq 14$ mentally unhealthy days during the past 30 days.

Evidence-based interventions (https:/www.cdc.gov/arthritis/ interventions/index.htm) have been reported to have a positive impact on arthritis outcomes $(22,23)$; however, interventions are underused and require more widespread dissemination. Physical activity is a proven strategy for managing arthritis symptoms and many other chronic conditions (22). For instance, a meta-analysis of community-based physical activity interventions indicated that physical activity can decrease pain and improve function by approximately $40 \%$ (22). Although persons with arthritis report typical barriers to being physically active (e.g., lack of time and lack of enjoyment), arthritis presents specific barriers (e.g., pain, functional limitations, depression, and fear of falling and injury) (28). Similarly, in a meta-analysis of self-management education interventions, participants experienced improvements of $10 \%-20 \%$ in confidence and skills to manage their condition and reductions in pain, fatigue, and depression (23). However, as this and other analyses illustrate, self-management education interventions are underused by adults with arthritis; nationally, only about $11 \%$ report ever having taken a course (19).

Arthritis is a common comorbid condition that might complicate the management of other chronic conditions (e.g., obesity, coronary heart disease, and diabetes), increase the negative outcomes of these conditions, and reduce quality of life $(18,29)$. The combination of arthritis and one of these chronic conditions has been associated with higher levels of physical inactivity (30-32). Moreover, arthritis also might hinder the ability of adults with prediabetes to engage in the level of physical activity recommended to prevent diabetes (33). Counseling persons with arthritis that physical activity can improve these outcomes (e.g., lower risk for diabetes) and improving availability of safe and effective physical activity programs in their local communities can be an effective strategy for reducing physical inactivity among these groups (e.g., adults with prediabetes or other comorbid conditions).

CDC funds arthritis programs in 12 state health departments and with national partners (e.g., Young Men's Christian Association [YMCA] and National Recreation and Park Association) to disseminate evidence-based interventions in their communities (https://www.cdc.gov/arthritis/ partners/funded-states.htm). State health departments, local community-based organizations, policymakers, and others can use the estimates at the state, territory, and county levels in this report to help identify local areas with need for evidence-based interventions. For example, physical activity programs such as EnhanceFitness, Walk With Ease, and Fit \& Strong! (https:// www.cdc.gov/arthritis/interventions/index.htm) could be disseminated to these areas. Several CDC-funded state health departments have been successful at reaching persons with arthritis with these evidence-based programs by partnering with YMCA of the USA and local parks and recreation departments.

\section{Limitations}

The findings in this report are subject to at least seven limitations. First, arthritis was self-reported and not confirmed by a health care professional; however, this case definition has been shown to have sufficient sensitivity for public health surveillance (34). Second, because BRFSS is a cross-sectional survey, a causal relation between risk factors (e.g., obesity) and arthritis cannot be established, although robust evidence exists that links obesity to an increased risk for knee osteoarthritis (the most common form of arthritis) (14). Third, social desirability bias might have a role in certain self-reported characteristics, with underreporting of BMI (35) and overreporting of leisuretime physical activity (36). Fourth, the 2015 BRFSS median 
response rate was $47.2 \%$ and ranged from $33.9 \%$ to $61.1 \%$, indicating potential nonresponse bias, although survey weights were applied to address this bias and improve external validity (27). Fifth, some of the morbidities potentially related to arthritis (e.g., physically or mentally unhealthy days) might be primarily affected by other conditions and thus might overestimate arthritis-specific impact. Sixth, the model used for county-level estimates did not account for complex sample design features, including potential geographic correlations between counties or states (i.e., observations for nearby counties and states might be clustered and therefore not independent). Finally, because county representativeness was not captured by BRFSS, model-based estimation other than direct survey estimation was used to generate prevalences at the county level. This approach has limitations that have been described elsewhere (11); however, the method has been tested through a comparison of model-based estimates with direct local survey estimates for certain other chronic conditions at the county level (37).

\section{Conclusion}

In 2015, the number of adults with arthritis continued to increase, matched projections of prevalence, and exceeded projections for arthritis-attributable activity limitations at the state level (38). The findings in this report describe the prevalence and health-related characteristics of arthritis across the United States. The findings also highlight geographic variability in these estimates, including gaps in arthritis management. Public health professionals can use this information to better understand and target evidencebased nonpharmaceutical interventions, such as arthritis self-management education and physical activity. These interventions can decrease the impact of arthritis, which in turn might help adults with arthritis better manage comorbid conditions such as obesity, coronary heart disease, and diabetes. These estimates demonstrate the need to create links in clinical and community settings that can enhance health care provider counseling for physical activity and weight loss and facilitate referrals to self-management education and physical activity interventions to address arthritis and related comorbidities.

\section{References}

1. Barbour KE, Helmick CG, Boring M, Brady TJ. Vital signs: prevalence of doctor-diagnosed arthritis and arthritis-attributable activity limitation-United States, 2013-2015. MMWR Morb Mortal Wkly Rep 2017;66:246-53. https://doi.org/10.15585/mmwr.mm6609e1

2. Barbour KE, Helmick CG, Boring M, Zhang X, Lu H, Holt JB. Prevalence of doctor-diagnosed arthritis at state and county levels-United States, 2014. MMWR Morb Mortal Wkly Rep 2016;65:489-94. https://doi. org/10.15585/mmwr.mm6519a2
3. Boring MA, Hootman JM, Liu Y, et al. Prevalence of arthritis and arthritis-attributable activity limitation by urban-rural county classification-United States, 2015. MMWR Morb Mortal Wkly Rep 2017;66:527-32. https://doi.org/10.15585/mmwr.mm6620a2

4. Barbour KE, Boring M, Helmick CG, Murphy LB, Qin J. Prevalence of severe joint pain among adults with doctor-diagnosed arthritisUnited States, 2002-2014. MMWR Morb Mortal Wkly Rep 2016;65:1052-6. https://doi.org/10.15585/mmwr.mm6539a2

5. Hootman JM, Helmick CG, Barbour KE, Theis KA, Boring MA. Updated projected prevalence of self-reported doctor-diagnosed arthritis and arthritis-attributable activity limitation among U.S. adults, 20152040. Arthritis Rheumatol 2016;68:1582-7. https://doi.org/10.1002/ art.39692

6. Murphy LB, Cisternas MG, Pasta DJ, Helmick CG, Yelin EH. Medical expenditures and earnings losses among US adults with arthritis in 2013. Arthritis Care Res (Hoboken) 2017. https://doi.org/10.1002/acr.23425

7. Gamble S, Mawokomatanda T, Xu F, et al. Surveillance for certain health behaviors and conditions among states and selected local areasBehavioral Risk Factor Surveillance System, United States, 2013 and 2014. MMWR Surveill Summ 2017;66(No. SS-16). https://doi. org/10.15585/mmwr.ss6616a1

8. CDC. Self-reported frequent mental distress among adults — United States, 1993-1996. MMWR Morb Mortal Wkly Rep 1998;47:326-31.

9. Bolen J, Schieb L, Hootman JM, et al. Differences in the prevalence and severity of arthritis among racial/ethnic groups in the United States, National Health Interview Survey, 2002, 2003, and 2006. Prev Chronic Dis 2010;7:A64.

10. Klein RJ, Schoenborn CA. Age adjustment using the 2000 projected US population. Healthy people statistical notes, no. 20. Hyattsville, MD: US Department of Health and Human Services, CDC, National Center for Health Statistics; 2001.

11. Zhang X, Holt JB, Lu H, et al. Multilevel regression and poststratification for small-area estimation of population health outcomes: a case study of chronic obstructive pulmonary disease prevalence using the Behavioral Risk Factor Surveillance System. Am J Epidemiol 2014;179:1025-33. https://doi.org/10.1093/aje/kwu018

12. Webster BH. Income, earnings, and poverty data from the 2005 American Community Survey. Darby, PA: Diane Publishing; 2010.

13. Di Giuseppe D, Discacciati A, Orsini N, Wolk A. Cigarette smoking and risk of rheumatoid arthritis: a dose-response meta-analysis. Arthritis Res Ther 2014;16:R61. https://doi.org/10.1186/ar4498

14. Nevitt MC. Obesity outcomes in disease management: clinical outcomes for osteoarthritis. Obes Res 2002;10(Suppl 1):33S-7S. https://doi. org/10.1038/oby.2002.187

15. Cooper C, McAlindon T, Coggon D, Egger P, Dieppe P. Occupational activity and osteoarthritis of the knee. Ann Rheum Dis 1994;53:90-3. https://doi.org/10.1136/ard.53.2.90

16. Murphy LB, Moss S, Do BT, et al. Annual incidence of knee symptoms and four knee osteoarthritis outcomes in the Johnston County Osteoarthritis Project. Arthritis Care Res (Hoboken) 2016;68:55-65. https://doi.org/10.1002/acr.22641

17. Moss AS, Murphy LB, Helmick CG, et al. Annual incidence rates of hip symptoms and three hip OA outcomes from a U.S. population-based cohort study: the Johnston County Osteoarthritis Project. Osteoarthritis Cartilage 2016;24:1518-27. https://doi.org/10.1016/j.joca.2016.04.012

18. Theis KA, Brady TJ, Helmick CG. No one dies of old age anymore: a coordinated approach to comorbidities and the rheumatic diseases. Arthritis Care Res (Hoboken) 2017;69:1-4. https://doi.org/10.1002/acr.23114

19. Murphy LB, Brady TJ, Boring MA, et al. Self-management education participation among US adults with arthritis: who's attending? Arthritis Care Res (Hoboken) 2017;69:1322-30. https://doi.org/10.1002/acr.23129

20. Barbour KE, Helmick CG, Boring M, Qin J, Pan L, Hootman JM. Obesity trends among adults with doctor-diagnosed arthritis 2009-2014. Arthritis Care Res (Hoboken) 2017;69:376-83. https://doi.org/10.1002/acr.22958 
21. Murphy LB, Hootman JM, Boring MA, et al. Leisure time physical activity among U.S. adults with arthritis, 2008-2015. Am J Prev Med 2017;53:345-54. https://doi.org/10.1016/j.amepre.2017.03.017

22. Kelley GA, Kelley KS, Hootman JM, Jones DL. Effects of communitydeliverable exercise on pain and physical function in adults with arthritis and other rheumatic diseases: a meta-analysis. Arthritis Care Res (Hoboken) 2011;63:79-93. https://doi.org/10.1002/acr.20347

23. Brady TJ, Murphy L, O'Colmain BJ, et al. A meta-analysis of health status, health behaviors, and healthcare utilization outcomes of the Chronic Disease Self-Management Program. Prev Chronic Dis 2013;10:120112. https://doi.org/10.5888/pcd10.120112

24. Baker NA, Barbour KE, Helmick CG, Zack MM, Al Snih S. Associations between arthritis and change in physical function in U.S. retirees. J Gerontol A Biol Sci Med Sci 2017;72:127-33. https://doi.org/10.1093/ gerona/glw075

25. Rubenstein LZ, Josephson KR. Falls and their prevention in elderly people: what does the evidence show? Med Clin North Am 2006;90:80724. https://doi.org/10.1016/j.mcna.2006.05.013

26. Barbour KE, Stevens JA, Helmick CG, et al. Falls and fall injuries among adults with arthritis-United States, 2012. MMWR Morb Mortal Wkly Rep 2014;63:379-83.

27. Furner SE, Hootman JM, Helmick CG, Bolen J, Zack MM. Health-related quality of life of US adults with arthritis: analysis of data from the behavioral risk factor surveillance system, 2003, 2005, and 2007. Arthritis Care Res (Hoboken) 2011;63:788-99. https://doi.org/10.1002/acr.20430

28. Brittain DR, Gyurcsik NC, McElroy M, Hillard SA. General and arthritis-specific barriers to moderate physical activity in women with arthritis. Womens Health Issues 2011;21:57-63. https://doi. org/10.1016/j.whi.2010.07.010

29. Qin J, Theis KA, Barbour KE, Helmick CG, Baker NA, Brady TJ. Impact of arthritis and multiple chronic conditions on selected life domains-United States, 2013. MMWR Morb Mortal Wkly Rep 2015;64:578-82.
30. Bolen J, Murphy L, Greenlund K, et al. Arthritis as a potential barrier to physical activity among adults with heart disease-United States, 2005 and 2007. MMWR Morb Mortal Wkly Rep 2009;58:165-9.

31. CDC. Arthritis as a potential barrier to physical activity among adults with diabetes-United States, 2005 and 2007. MMWR Morb Mortal Wkly Rep 2008;57:486-9.

32. CDC. Arthritis as a potential barrier to physical activity among adults with obesity-United States, 2007 and 2009. MMWR Morb Mortal Wkly Rep 2011;60:614-8.

33. Strauss SM, McCarthy M. Arthritis-related limitations predict insufficient physical activity in adults with prediabetes identified in the NHANES 2011-2014. Diabetes Educ 2017;43:163-70. https://doi. org/10.1177/0145721717691849

34. Sacks JJ, Harrold LR, Helmick CG, Gurwitz JH, Emani S, Yood RA. Validation of a surveillance case definition for arthritis. J Rheumatol 2005;32:340-7.

35. Stommel M, Schoenborn CA. Accuracy and usefulness of BMI measures based on self-reported weight and height: findings from the NHANES \& NHIS 2001-2006. BMC Public Health 2009;9:421. https://doi. org/10.1186/1471-2458-9-421

36. Sallis JF, Saelens BE. Assessment of physical activity by self-report: status, limitations, and future directions. Res Q Exerc Sport 2000;71(Suppl 2):1-14. https://doi.org/10.1080/02701367.2000.11082780

37. Zhang X, Holt JB, Yun S, Lu H, Greenlund KJ, Croft JB. Validation of multilevel regression and poststratification methodology for small area estimation of health indicators from the behavioral risk factor surveillance system. Am J Epidemiol 2015;182:127-37. https://doi.org/10.1093/ aje/kwv002

38. CDC. Projected state-specific increases in self-reported doctor-diagnosed arthritis and arthritis-attributable activity limitations-United States, 2005-2030. MMWR Morb Mortal Wkly Rep 2007;56:423-5. 
TABLE 1. Prevalence of arthritis,* by area - Behavioral Risk Factor Surveillance System, United States, 2015

\begin{tabular}{|c|c|c|c|c|c|}
\hline Area & No. of respondents & $\begin{array}{l}\text { No. of respondents } \\
\text { with arthritis }\end{array}$ & $\begin{array}{l}\text { Weighted population } \\
\text { with arthritis } \\
\text { (rounded to } 1,000 \text { s) }\end{array}$ & $\begin{array}{l}\text { Unadjusted } \\
\%(95 \% \mathrm{Cl})\end{array}$ & $\begin{array}{c}\text { Age-standardized } \\
\%^{\dagger}(95 \% \mathrm{Cl})\end{array}$ \\
\hline Alabama & 7,950 & 3,307 & $1,248,000$ & $33.3(31.9-34.6)$ & $30.4(29.2-31.7)$ \\
\hline Alaska & 3,657 & 1,028 & 117,000 & $21.2(19.3-23.2)$ & $21.5(19.7-23.3)$ \\
\hline Arizona & 7,946 & 2,663 & $1,222,000$ & $23.6(22.5-24.8)$ & $21.8(20.7-22.9)$ \\
\hline Arkansas & 5,256 & 2,228 & 672,000 & $29.7(27.8-31.7)$ & $27.1(25.4-28.9)$ \\
\hline California & 12,601 & 2,803 & $5,719,000$ & $19.1(18.3-20.0)$ & $18.3(17.6-19.1)$ \\
\hline Colorado & 13,537 & 4,136 & 949,000 & $22.7(21.8-23.7)$ & $21.8(20.9-22.7)$ \\
\hline Connecticut & 11,899 & 3,962 & 690,000 & $24.5(23.5-25.5)$ & $21.6(20.8-22.5)$ \\
\hline Delaware & 4,070 & 1,471 & 207,000 & $28.1(26.3-29.9)$ & $24.6(23.1-26.2)$ \\
\hline District of Columbia & 3,994 & 1,316 & 101,000 & $18.5(16.7-20.4)$ & $19.9(18.3-21.7)$ \\
\hline Florida & 9,739 & 3,454 & $4,154,000$ & $25.9(24.8-27.0)$ & $21.5(20.6-22.5)$ \\
\hline Georgia & 4,678 & 1,660 & $1,890,000$ & $24.6(23.1-26.1)$ & $23.6(22.3-24.9)$ \\
\hline Hawaii & 7,163 & 1,757 & 211,000 & $18.9(17.8-20.1)$ & $17.2(16.2-18.3)$ \\
\hline Idaho & 5,802 & 2,031 & 309,000 & $25.3(23.8-26.8)$ & $23.2(22.0-24.5)$ \\
\hline Illinois & 5,289 & 1,671 & $2,308,000$ & $23.3(22.0-24.7)$ & $21.6(20.4-22.7)$ \\
\hline Indiana & 6,067 & 2,273 & $1,390,000$ & $27.6(26.1-29.1)$ & $25.4(24.1-26.7)$ \\
\hline lowa & 6,227 & 2,145 & 619,000 & $25.9(24.6-27.2)$ & $23.2(22.1-24.4)$ \\
\hline Kansas & 23,236 & 7,320 & 536,000 & $24.5(23.9-25.2)$ & $22.7(22.2-23.3)$ \\
\hline Kentucky & 8,806 & 3,565 & $1,087,000$ & $32.0(30.5-33.5)$ & $29.3(27.9-30.8)$ \\
\hline Louisiana & 4,716 & 1,748 & 989,000 & $27.9(26.4-29.5)$ & $26.2(24.8-27.7)$ \\
\hline Maine & 9,063 & 3,459 & 332,000 & $31.0(29.7-32.3)$ & $26.4(25.2-27.6)$ \\
\hline Maryland & 12,598 & 4,631 & $1,096,000$ & $23.5(22.2-24.9)$ & $21.5(20.4-22.8)$ \\
\hline Massachusetts & 9,294 & 2,842 & $1,300,000$ & $24.1(23.0-25.3)$ & $22.0(21.0-23.0)$ \\
\hline Michigan & 8,935 & 3,224 & $2,305,000$ & $30.0(28.9-31.1)$ & $27.0(26.0-28.0)$ \\
\hline Minnesota & 16,761 & 4,666 & 907,000 & $21.6(20.9-22.3)$ & $19.7(19.1-20.4)$ \\
\hline Mississippi & 6,035 & 2,431 & 647,000 & $28.6(27.1-30.1)$ & $26.6(25.3-28.0)$ \\
\hline Missouri & 7,307 & 2,808 & $1,372,000$ & $29.3(27.9-30.8)$ & $26.8(25.5-28.2)$ \\
\hline Montana & 6,051 & 2,123 & 216,000 & $26.8(25.4-28.3)$ & $23.9(22.5-25.4)$ \\
\hline Nebraska & 17,561 & 5,522 & 334,000 & $23.4(22.6-24.3)$ & $21.5(20.7-22.3)$ \\
\hline Nevada & 2,926 & 918 & 477,000 & $21.5(19.5-23.8)$ & $20.1(18.2-22.2)$ \\
\hline New Hampshire & 7,022 & 2,588 & 282,000 & $26.6(25.3-27.9)$ & $23.0(21.9-24.2)$ \\
\hline New Jersey & 11,465 & 3,442 & $1,590,000$ & $22.9(21.8-24.1)$ & $20.5(19.5-21.5)$ \\
\hline New Mexico & 6,734 & 2,248 & 386,000 & $24.5(23.1-25.9)$ & $22.2(21.0-23.5)$ \\
\hline New York & 12,357 & 3,921 & $3,629,000$ & $23.4(22.5-24.3)$ & $21.5(20.6-22.3)$ \\
\hline North Carolina & 6,698 & 2,144 & $2,089,000$ & $26.9(25.7-28.2)$ & $24.9(23.8-26.0)$ \\
\hline North Dakota & 4,972 & 1,585 & 134,000 & $22.9(21.5-24.3)$ & $21.6(20.4-22.9)$ \\
\hline Ohio & 11,929 & 4,730 & $2,547,000$ & $28.4(27.2-29.7)$ & $25.3(24.2-26.4)$ \\
\hline Oklahoma & 6,943 & 2,692 & 813,000 & $27.7(26.3-29.1)$ & $25.7(24.5-27.0)$ \\
\hline Oregon & 5,359 & 1,828 & 838,000 & $26.8(25.4-28.2)$ & $24.5(23.2-25.8)$ \\
\hline Pennsylvania & 5,740 & 2,059 & $2,937,000$ & $29.2(27.8-30.7)$ & $25.7(24.4-27.0)$ \\
\hline Rhode Island & 6,206 & 2,244 & 226,000 & $26.9(25.5-28.4)$ & $24.2(22.9-25.6)$ \\
\hline South Carolina & 11,607 & 4,405 & $1,105,000$ & $29.1(28.1-30.2)$ & $26.3(25.3-27.2)$ \\
\hline South Dakota & 7,221 & 2,389 & 158,000 & $24.3(22.8-25.9)$ & $21.8(20.5-23.2)$ \\
\hline Tennessee & 5,979 & 2,466 & $1,630,000$ & $32.0(30.3-33.7)$ & $29.4(27.9-31.1)$ \\
\hline Texas & 14,697 & 4,522 & $4,055,000$ & $20.0(19.0-21.1)$ & $19.8(18.9-20.8)$ \\
\hline Utah & 11,401 & 2,929 & 407,000 & $19.6(18.8-20.4)$ & $20.8(20.1-21.6)$ \\
\hline Vermont & 6,489 & 2,089 & 136,000 & $27.0(25.7-28.3)$ & $23.4(22.3-24.6)$ \\
\hline Virginia & 8,646 & 2,684 & $1,513,000$ & $23.2(22.1-24.3)$ & $21.6(20.6-22.6)$ \\
\hline Washington & 16,116 & 5,481 & $1,346,000$ & $24.5(23.6-25.3)$ & $22.6(21.9-23.4)$ \\
\hline West Virginia & 5,957 & 2,537 & 557,000 & $38.0(36.6-39.4)$ & $33.6(32.3-34.9)$ \\
\hline Wisconsin & 6,188 & 1,984 & $1,104,000$ & $24.7(23.3-26.2)$ & $22.1(20.8-23.5)$ \\
\hline Wyoming & 5,492 & 2,021 & 116,000 & $25.9(24.2-27.5)$ & $24.1(22.6-25.8)$ \\
\hline Median (Range) ${ }^{\S}$ & & & & $25.3(18.5-38.0)$ & $23.0(17.2-33.6)$ \\
\hline Guam & 1,669 & 270 & 17,000 & $15.8(13.5-18.4)$ & $17.9(15.5-20.6)$ \\
\hline Puerto Rico & 5,405 & 1,616 & 635,000 & $22.8(21.5-24.0)$ & $20.6(19.5-21.7)$ \\
\hline
\end{tabular}

Abbreviation: $\mathrm{Cl}=$ confidence interval.

* Doctor-diagnosed arthritis was defined as a yes response to the question "Has a doctor, nurse, or other health professional ever told you that you have some form of arthritis, rheumatoid arthritis, gout, lupus, or fibromyalgia?"

${ }^{\dagger}$ Age standardized to the 2000 U.S. projected population, using three age groups: $18-44,45-64$, and $\geq 65$ years.

$\S$ Median and range were calculated from estimates for the 50 states and the District of Columbia. 


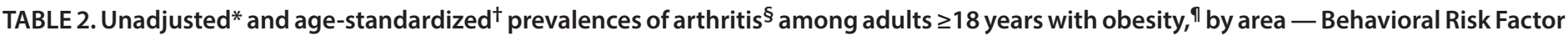
Surveillance System, United States, 2015

\begin{tabular}{|c|c|c|c|c|}
\hline Area & $\begin{array}{l}\text { No. of respondents } \\
\text { with obesity }\end{array}$ & $\begin{array}{l}\text { Weighted population } \\
\text { with arthritis and obesity } \\
\text { (rounded to } 1,000 \text { s) }\end{array}$ & $\begin{array}{l}\text { Unadjusted } \\
\%(95 \% \mathrm{Cl})\end{array}$ & $\begin{array}{c}\text { Age-standardized } \\
\%(95 \% \mathrm{Cl})\end{array}$ \\
\hline Alabama & 2,626 & 512,000 & $41.4(38.9-43.9)$ & $37.9(35.7-40.2)$ \\
\hline Alaska & 1,059 & 46,000 & $29.9(26.1-34.0)$ & $28.5(24.9-32.4)$ \\
\hline Arizona & 1,892 & 398,000 & $30.0(27.4-32.7)$ & $27.5(25.3-29.7)$ \\
\hline Arkansas & 1,593 & 275,000 & $37.7(33.9-41.6)$ & $35.0(31.5-38.7)$ \\
\hline California & 2,808 & $1,749,000$ & $26.4(24.4-28.6)$ & $24.8(23.1-26.6)$ \\
\hline Colorado & 2,666 & 250,000 & $32.8(30.3-35.4)$ & $29.4(27.2-31.7)$ \\
\hline Connecticut & 2,817 & 228,000 & $35.0(32.7-37.4)$ & $29.9(27.8-32.0)$ \\
\hline Delaware & 1,145 & 70,000 & $35.6(31.9-39.3)$ & $30.2(27.3-33.4)$ \\
\hline District of Columbia & 899 & 41,000 & $36.8(31.2-42.8)$ & $31.6(26.6-37.0)$ \\
\hline Florida & 2,296 & $1,381,000$ & $34.9(32.4-37.6)$ & $28.3(26.1-30.6)$ \\
\hline Georgia & 1,340 & 759,000 & $35.4(32.3-38.8)$ & $31.3(28.7-34.0)$ \\
\hline Hawaii & 1,509 & 67,000 & $27.6(24.8-30.6)$ & $26.8(24.0-29.8)$ \\
\hline Idaho & 1,596 & 105,000 & $32.0(29.0-35.1)$ & $29.0(26.4-31.8)$ \\
\hline Illinois & 1,547 & 946,000 & $32.4(29.7-35.2)$ & $28.4(26.1-30.9)$ \\
\hline Indiana & 1,804 & 537,000 & $36.2(33.2-39.4)$ & $32.4(29.7-35.3)$ \\
\hline lowa & 1,805 & 241,000 & $34.4(31.8-37.2)$ & $30.5(28.1-33.0)$ \\
\hline Kansas & 6,318 & 194,000 & $33.6(32.2-34.9)$ & $30.1(28.9-31.4)$ \\
\hline Kentucky & 2,871 & 457,000 & $41.7(38.8-44.7)$ & $38.0(35.2-41.0)$ \\
\hline Louisiana & 1,570 & 419,000 & $35.6(32.6-38.7)$ & $33.3(30.6-36.1)$ \\
\hline Maine & 2,567 & 122,000 & $40.3(37.8-43.0)$ & $34.9(32.3-37.7)$ \\
\hline Maryland & 3,437 & 448,000 & $36.9(33.7-40.1)$ & $32.5(29.5-35.7)$ \\
\hline Massachusetts & 2,061 & 422,000 & $37.2(34.4-40.2)$ & $31.5(28.9-34.2)$ \\
\hline Michigan & 2,582 & 875,000 & $39.3(37.0-41.6)$ & 34.8 (32.7-36.9) \\
\hline Minnesota & 4,213 & 321,000 & $32.0(30.3-33.7)$ & $27.7(26.0-29.5)$ \\
\hline Mississippi & 1,964 & 260,000 & $34.4(31.6-37.4)$ & 32.8 (30.4-35.4) \\
\hline Missouri & 2,219 & 518,000 & $37.2(34.5-40.0)$ & $33.7(31.1-36.3)$ \\
\hline Montana & 1,430 & 62,000 & $35.7(32.3-39.1)$ & $30.4(27.2-33.8)$ \\
\hline Nebraska & 5,371 & 134,000 & $32.3(30.5-34.2)$ & $28.4(26.7-30.2)$ \\
\hline Nevada & 700 & 155,000 & $28.6(23.9-33.8)$ & $26.4(21.9-31.6)$ \\
\hline New Hampshire & 1,717 & 94,000 & $37.0(34.1-40.0)$ & $31.4(28.7-34.3)$ \\
\hline New Jersey & 2,778 & 539,000 & $34.3(31.6-37.0)$ & $29.2(26.9-31.7)$ \\
\hline New Mexico & 1,728 & 127,000 & $30.3(27.3-33.4)$ & $29.3(26.6-32.2)$ \\
\hline New York & 2,933 & $1,221,000$ & $34.6(32.4-36.9)$ & $30.9(28.8-33.2)$ \\
\hline North Carolina & 1,808 & 780,000 & $37.2(34.6-39.9)$ & $33.5(31.1-36.0)$ \\
\hline North Dakota & 1,477 & 51,000 & $30.7(28.0-33.6)$ & $27.2(24.8-29.6)$ \\
\hline Ohio & 3,420 & 947,000 & $38.2(35.7-40.8)$ & $32.6(30.3-35.1)$ \\
\hline Oklahoma & 2,126 & 329,000 & $35.5(32.9-38.2)$ & $33.0(30.6-35.4)$ \\
\hline Oregon & 1401 & 302,000 & $35.3(32.3-38.4)$ & $32.0(29.2-34.9)$ \\
\hline Pennsylvania & 5,740 & $1,114,000$ & $39.6(36.6-42.7)$ & $33.7(30.9-36.6)$ \\
\hline Rhode Island & 6,206 & 74,000 & $36.9(33.6-40.3)$ & $31.8(28.7-35.0)$ \\
\hline South Carolina & 11,607 & 437,000 & $38.5(36.3-40.7)$ & $34.9(32.9-36.9)$ \\
\hline South Dakota & 7,221 & 60,000 & $31.7(28.6-35.0)$ & $28.3(25.6-31.1)$ \\
\hline Tennessee & 5,979 & 640,000 & $40.7(37.4-44.1)$ & $37.6(34.5-40.9)$ \\
\hline Texas & 14,697 & $1,518,000$ & $26.2(24.0-28.4)$ & $24.6(22.9-26.4)$ \\
\hline Utah & 11,401 & 137,000 & $29.3(27.3-31.4)$ & $28.0(26.2-29.9)$ \\
\hline Vermont & 6,489 & 43,000 & $37.1(34.1-40.1)$ & $31.2(28.4-34.2)$ \\
\hline Virginia & 8,646 & 584,000 & $33.0(30.5-35.5)$ & $29.6(27.2-32.0)$ \\
\hline Washington & 16,116 & 454,000 & $34.5(32.6-36.5)$ & $29.8(28.1-31.5)$ \\
\hline West Virginia & 5,957 & 223,000 & $46.6(44.1-49.2)$ & $41.2(38.7-43.7)$ \\
\hline Wisconsin & 6,188 & 417,000 & $32.6(29.8-35.6)$ & $28.2(25.6-31.1)$ \\
\hline Wyoming & 5,492 & 41,000 & $34.1(30.6-37.7)$ & $31.2(28.1-34.5)$ \\
\hline Median (Range)** & & & $35.0(26.2-46.6)$ & $30.9(24.6-41.2)$ \\
\hline Guam & 1,669 & 7,000 & $20.3(15.9-25.5)$ & $23.4(19.0-28.5)$ \\
\hline Puerto Rico & 5,405 & 215,000 & $27.5(25.0-30.2)$ & $25.7(23.4-28.2)$ \\
\hline
\end{tabular}

Abbreviation: $\mathrm{Cl}=$ confidence interval.

* The numerator was the estimated number of adults with arthritis and obesity (body mass index $\geq 30$ ). The denominator was the estimated number of adults with obesity.

† Age standardized to the 2000 U.S. projected population, using three age groups: $18-44,45-64$, and $\geq 65$ years.

$\S$ Doctor-diagnosed arthritis was defined as a yes response to the question "Has a doctor, nurse, or other health professional ever told you that you have some form of arthritis, rheumatoid arthritis, gout, lupus, or fibromyalgia?"

" Body mass index $\geq 30$; calculated from self-reported height and weight.

** Median and range were calculated from estimates for the 50 states and the District of Columbia. 
TABLE 3. Unadjusted* and age-standardized ${ }^{\dagger}$ prevalences of arthritis ${ }^{\S}$ among adults aged $\geq 18$ years with coronary heart disease, ${ }^{\natural}$ by area Behavioral Risk Factor Surveillance System, United States, 2015

\begin{tabular}{|c|c|c|c|c|}
\hline Area & $\begin{array}{l}\text { No. of respondents with } \\
\text { coronary heart disease }\end{array}$ & $\begin{array}{l}\text { Weighted population with } \\
\text { arthritis and coronary heart } \\
\text { disease (rounded to } 1,000 \text { s) }\end{array}$ & $\begin{array}{l}\text { Unadjusted } \\
\%(95 \% \mathrm{Cl})\end{array}$ & $\begin{array}{c}\text { Age-standardized } \\
\% *(95 \% \mathrm{Cl})\end{array}$ \\
\hline Alabama & 874 & 196,000 & $64.3(59.7-68.7)$ & $57.0(47.0-66.6)$ \\
\hline Alaska & 223 & 12,000 & $49.1(38.0-60.2)$ & $31.3(21.8-42.6)$ \\
\hline Arizona & 732 & 164,000 & $51.6(46.1-57.1)$ & $36.9(27.8-47.0)$ \\
\hline Arkansas & 714 & 122,000 & $64.6(58.5-70.3)$ & $57.8(41.8-72.4)$ \\
\hline California & 701 & 708,000 & $49.0(43.8-54.2)$ & $38.1(28.7-48.5)$ \\
\hline Colorado & 857 & 99,000 & $53.4(48.3-58.4)$ & $48.2(35.9-60.7)$ \\
\hline Connecticut & 945 & 80,000 & $52.1(47.7-56.5)$ & $41.2(30.8-52.4)$ \\
\hline Delaware & 385 & 30,000 & $57.5(49.5-65.1)$ & $44.4(27.2-63.0)$ \\
\hline District of Columbia & 286 & 11,000 & $45.9(34.8-57.3)$ & $25.6(20.0-32.3)$ \\
\hline Florida & 1,031 & 667,000 & $56.2(51.9-60.5)$ & $43.0(31.8-54.9)$ \\
\hline Georgia & 454 & 301,000 & $59.0(52.6-65.0)$ & $48.3(34.6-62.3)$ \\
\hline Hawaii & 409 & 22,000 & $43.5(36.7-50.5)$ & $39.1(26.9-52.8)$ \\
\hline Idaho & 469 & 37,000 & $53.8(46.4-61.0)$ & $36.7(27.2-47.5)$ \\
\hline Illinois & 457 & 317,000 & $53.0(47.0-58.9)$ & $39.1(26.0-54.1)$ \\
\hline Indiana & 672 & 239,000 & $60.9(55.4-66.2)$ & $52.2(39.6-64.5)$ \\
\hline lowa & 516 & 86,000 & $59.9(54.6-65.0)$ & $72.6(60.6-82.1)$ \\
\hline Kansas & 1,894 & 72,000 & $56.5(53.8-59.1)$ & $43.5(36.8-50.3)$ \\
\hline Kentucky & 1,055 & 187,000 & $59.3(54.3-64.1)$ & $48.4(38.9-57.9)$ \\
\hline Louisiana & 527 & 173,000 & $61.1(55.4-66.5)$ & $55.8(43.2-67.7)$ \\
\hline Maine & 824 & 51,000 & $60.8(56.1-65.3)$ & $52.6(40.0-65.0)$ \\
\hline Maryland & 1,126 & 140,000 & $52.3(46.5-58.0)$ & $38.9(27.5-51.7)$ \\
\hline Massachusetts & 656 & 181,000 & $56.8(51.0-62.4)$ & $48.1(35.1-61.5)$ \\
\hline Michigan & 788 & 344,000 & $62.1(57.9-66.2)$ & $45.7(35.2-56.6)$ \\
\hline Minnesota & 1,131 & 110,000 & $50.6(47.0-54.1)$ & $35.8(27.9-44.7)$ \\
\hline Mississippi & 659 & 110,000 & $58.2(52.3-63.9)$ & $43.5(34.0-53.4)$ \\
\hline Missouri & 780 & 204,000 & $58.3(53.3-63.1)$ & $38.2(29.2-48.1)$ \\
\hline Montana & 502 & 26,000 & $57.9(51.6-63.9)$ & $44.0(27.3-62.2)$ \\
\hline Nebraska & 1,447 & 43,000 & $51.8(47.9-55.7)$ & $35.8(29.5-42.7)$ \\
\hline Nevada & 247 & 86,000 & $63.0(52.9-72.0)$ & $41.6(27.5-57.3)$ \\
\hline New Hampshire & 614 & 33,000 & $55.2(49.9-60.3)$ & $43.4(27.6-60.7)$ \\
\hline New Jersey & 848 & 215,000 & $55.9(50.6-61.0)$ & $50.4(36.5-64.2)$ \\
\hline New Mexico & 572 & 50,000 & $56.0(49.8-62.0)$ & $30.5(25.8-35.7)$ \\
\hline New York & 959 & 510,000 & $57.3(53.0-61.6)$ & $56.1(44.4-67.3)$ \\
\hline North Carolina & 580 & 313,000 & $57.9(52.8-62.8)$ & $44.5(33.4-56.2)$ \\
\hline North Dakota & 414 & 18,000 & $54.1(47.9-60.1)$ & $55.2(35.8-73.2)$ \\
\hline
\end{tabular}

See table footnotes on next page. 
TABLE 3. (Continued) Unadjusted* and age-standardized ${ }^{\dagger}$ prevalences of arthritis ${ }^{\S}$ among adults aged $\geq 18$ years with coronary heart disease, ${ }^{\natural}$ by area - Behavioral Risk Factor Surveillance System, United States, 2015

\begin{tabular}{|c|c|c|c|c|}
\hline Area & $\begin{array}{l}\text { No. of respondents with } \\
\text { coronary heart disease }\end{array}$ & $\begin{array}{l}\text { Weighted population with } \\
\text { arthritis and coronary heart } \\
\text { disease (rounded to } 1,000 \text { s) }\end{array}$ & $\begin{array}{l}\text { Unadjusted } \\
\%(95 \% \mathrm{Cl})\end{array}$ & $\begin{array}{c}\text { Age-standardized } \\
\% *(95 \% \mathrm{Cl})\end{array}$ \\
\hline Ohio & 1,295 & 382,000 & $61.0(56.2-65.6)$ & $45.3(32.4-58.8)$ \\
\hline Oklahoma & 838 & 161,000 & $65.3(60.2-70.2)$ & $47.9(36.4-59.6)$ \\
\hline Oregon & 398 & 97,000 & $56.4(50.1-62.6)$ & $46.4(30.9-62.7)$ \\
\hline Pennsylvania & 485 & 412,000 & $58.4(52.4-64.2)$ & $49.9(33.5-66.3)$ \\
\hline Rhode Island & 534 & 30,000 & $59.8(53.7-65.6)$ & $60.3(44.3-74.3)$ \\
\hline South Carolina & 1,134 & 162,000 & $62.0(58.0-65.8)$ & $51.0(41.3-60.7)$ \\
\hline South Dakota & 715 & 28,000 & $61.1(54.9-66.9)$ & $50.8(36.6-64.9)$ \\
\hline Tennessee & 703 & 271,000 & $63.2(58.1-68.0)$ & $55.1(42.7-66.9)$ \\
\hline Texas & 1,362 & 606,000 & $49.9(44.3-55.5)$ & $36.8(28.7-45.8)$ \\
\hline Utah & 618 & 44,000 & $53.4(48.3-58.5)$ & $40.2(30.6-50.6)$ \\
\hline Vermont & 477 & 19,000 & $57.8(52.0-63.3)$ & $43.8(30.9-57.6)$ \\
\hline Virginia & 637 & 182,000 & $51.5(46.4-56.5)$ & 36.5 (28.9-44.8) \\
\hline Washington & 1,310 & 180,000 & $57.4(53.5-61.3)$ & $47.1(38.7-55.8)$ \\
\hline West Virginia & 755 & 102,000 & $63.8(59.7-67.7)$ & $53.7(44.1-63.1)$ \\
\hline Wisconsin & 494 & 134,000 & $48.9(42.6-55.2)$ & $35.9(25.7-47.7)$ \\
\hline Wyoming & 564 & 16,000 & $58.6(52.0-64.9)$ & $58.6(39.4-75.5)$ \\
\hline Median (Range) ${ }^{* *}$ & & & $57.4(43.5-65.3)$ & $44.5(25.6-72.6)$ \\
\hline Guam & 88 & 3,000 & $49.1(33.5-64.9)$ & $42.2(22.3-65.0)$ \\
\hline Puerto Rico & 586 & 126,000 & $49.2(44.3-54.2)$ & $37.3(30.2-44.9)$ \\
\hline
\end{tabular}

Abbreviation: $\mathrm{Cl}=$ confidence interval.

* The numerator was the estimated number of adults with arthritis and coronary heart disease. The denominator was the estimated number of adults with coronary heart disease.

${ }^{+}$Age standardized to the 2000 U.S. projected population, using three age groups: $18-44,45-64$, and $\geq 65$ years.

$\S$ Doctor-diagnosed arthritis was defined as a yes response to the question "Has a doctor, nurse, or other health professional ever told you that you have some form of arthritis, rheumatoid arthritis, gout, lupus, or fibromyalgia?"

" Doctor-diagnosed coronary heart disease was defined as a yes response to either of the following two questions: "Has a doctor, nurse, or other health professional ever told you that you had a heart attack, also called a myocardial infarction?" or "Has a doctor, nurse, or other health professional ever told you that you had angina or coronary heart disease?" Those who answered yes to either question were classified as having coronary heart disease. Those who answered no to both questions were classified as not having coronary heart disease.

** Median and range were calculated from estimates for the 50 states and the District of Columbia. 
TABLE 4. Unadjusted* and age-standardized ${ }^{\dagger}$ prevalences of arthritis ${ }^{\S}$ among adults aged $\geq 18$ years with diabetes, ${ }^{\Re}$ by area — Behavioral Risk Factor Surveillance System, United States, 2015

\begin{tabular}{|c|c|c|c|c|}
\hline Area & $\begin{array}{l}\text { No. of respondents } \\
\text { with diabetes }\end{array}$ & $\begin{array}{l}\text { Weighted population with } \\
\text { arthritis and diabetes } \\
\text { (rounded to } 1,000 \text { s) }\end{array}$ & $\begin{array}{l}\text { Unadjusted } \\
\%(95 \% \mathrm{Cl})\end{array}$ & $\begin{array}{c}\text { Age-standardized } \\
\% *(95 \% \mathrm{CI})\end{array}$ \\
\hline Alabama & 1,355 & 283,000 & $56.4(52.7-60.0)$ & $43.8(38.0-49.7)$ \\
\hline Alaska & 346 & 19,000 & $44.4(35.3-53.8)$ & $46.0(29.6-63.4)$ \\
\hline Arizona & 1,095 & 238,000 & 45.7 (41.6-49.9) & $32.6(27.0-38.8)$ \\
\hline Arkansas & 951 & 167,000 & $58.9(53.7-64.0)$ & $48.6(38.4-58.9)$ \\
\hline California & 1,283 & $1,088,000$ & $36.4(32.8-40.2)$ & $27.1(23.1-31.5)$ \\
\hline Colorado & 1,216 & 132,000 & $47.0(42.9-51.1)$ & $37.3(30.3-44.9)$ \\
\hline Connecticut & 1,379 & 117,000 & $45.5(41.8-49.2)$ & $30.1(25.0-35.6)$ \\
\hline Delaware & 606 & 42,000 & $50.0(44.5-55.4)$ & $35.4(26.8-44.9)$ \\
\hline District of Columbia & 544 & 22,000 & $47.0(39.2-55.0)$ & $28.2(22.8-34.2)$ \\
\hline Florida & 1,394 & 958,000 & $53.0(49.2-56.7)$ & $35.6(28.9-43.0)$ \\
\hline Georgia & 752 & 453,000 & $52.2(47.4-56.9)$ & $40.0(30.8-49.9)$ \\
\hline Hawaii & 722 & 37,000 & 38.7 (34.0-43.7) & $32.0(24.9-40.0)$ \\
\hline Idaho & 678 & 46,000 & $46.8(41.7-52.0)$ & $37.0(28.6-46.2)$ \\
\hline Illinois & 680 & 452,000 & $46.1(41.3-50.9)$ & $34.2(25.7-44.0)$ \\
\hline Indiana & 885 & 297,000 & $51.5(46.6-56.3)$ & $37.6(30.9-44.9)$ \\
\hline lowa & 753 & 110,000 & $52.1(47.4-56.7)$ & $32.2(26.3-38.7)$ \\
\hline Kansas & 2,863 & 106,000 & $50.4(48.2-52.6)$ & $37.1(33.8-40.6)$ \\
\hline Kentucky & 1,457 & 253,000 & $55.9(51.5-60.3)$ & $45.4(37.9-53.0)$ \\
\hline Louisiana & 793 & 241,000 & $53.7(49.1-58.4)$ & $41.5(33.7-49.7)$ \\
\hline Maine & 1,083 & 62,000 & $58.2(54.0-62.2)$ & $53.7(43.8-63.3)$ \\
\hline Maryland & 1,854 & 207,000 & $43.5(39.1-48.1)$ & $34.8(27.2-43.3)$ \\
\hline Massachusetts & 983 & 230,000 & $48.4(43.8-53.0)$ & $37.0(30.3-44.2)$ \\
\hline Michigan & 1,087 & 438,000 & $53.2(49.5-56.9)$ & $40.6(34.9-46.5)$ \\
\hline Minnesota & 1,637 & 150,000 & $47.8(44.8-50.9)$ & $36.9(30.6-43.6)$ \\
\hline Mississippi & 1,151 & 172,000 & $51.7(47.5-55.8)$ & $39.7(33.6-46.0)$ \\
\hline Missouri & 1,154 & 297,000 & $55.5(51.3-59.6)$ & $53.7(44.9-62.2)$ \\
\hline Montana & 652 & 34,000 & $53.9(48.2-59.5)$ & $46.4(34.2-59.1)$ \\
\hline Nebraska & 2,046 & 60,000 & $48.0(44.7-51.3)$ & $30.7(26.5-35.1)$ \\
\hline Nevada & 337 & 89,000 & $41.8(33.9-50.1)$ & $28.9(19.1-41.2)$ \\
\hline New Hampshire & 834 & 46,000 & $53.2(48.6-57.8)$ & $36.3(28.4-45.0)$ \\
\hline New Jersey & 1,314 & 302,000 & $48.3(44.1-52.6)$ & $38.3(29.4-48.0)$ \\
\hline New Mexico & 919 & 83,000 & $46.5(41.7-51.3)$ & $33.1(27.2-39.5)$ \\
\hline New York & 1,469 & 730,000 & $48.1(44.6-51.6)$ & $38.8(32.4-45.7)$ \\
\hline North Carolina & 855 & 440,000 & $53.4(49.4-57.4)$ & 40.5 (33.9-47.6) \\
\hline North Dakota & 565 & 22,000 & $43.8(38.6-49.1)$ & $27.4(21.7-33.9)$ \\
\hline Ohio & 1,861 & 531,000 & $53.8(50.1-57.5)$ & 39.7 (33.0-46.9) \\
\hline Oklahoma & 1,091 & 188,000 & $55.0(50.9-59.0)$ & $44.2(36.6-52.1)$ \\
\hline Oregon & 655 & 157,000 & $48.0(43.1-52.9)$ & $40.0(31.1-49.5)$ \\
\hline Pennsylvania & 715 & 575,000 & $55.2(50.3-60.1)$ & $40.0(31.0-49.7)$ \\
\hline Rhode Island & 748 & 39,000 & $51.5(46.4-56.6)$ & $42.9(29.9-56.9)$ \\
\hline South Carolina & 1,837 & 254,000 & $56.9(53.6-60.2)$ & $47.6(41.4-54.0)$ \\
\hline South Dakota & 862 & 28,000 & $46.9(41.2-52.6)$ & $31.6(25.4-38.4)$ \\
\hline Tennessee & 998 & 348,000 & $54.3(49.6-59.0)$ & $42.2(35.4-49.4)$ \\
\hline Texas & 2,269 & 977,000 & $42.4(38.4-46.6)$ & $27.8(24.4-31.5)$ \\
\hline Utah & 1,018 & 68,000 & $46.7(42.8-50.6)$ & $33.0(27.5-39.0)$ \\
\hline Vermont & 625 & 20,000 & $49.3(44.4-54.3)$ & $37.5(30.1-45.5)$ \\
\hline Virginia & 1,129 & 328,000 & $48.8(44.7-53.0)$ & $34.3(29.6-39.4)$ \\
\hline Washington & 1,782 & 219,000 & $47.8(44.5-51.0)$ & $35.4(30.2-41.1)$ \\
\hline West Virginia & 962 & 132,000 & $62.4(58.8-65.9)$ & $52.3(46.1-58.4)$ \\
\hline Wisconsin & 678 & 161,000 & $43.4(38.2-48.8)$ & $28.3(22.9-34.4)$ \\
\hline Wyoming & 678 & 19,000 & $51.7(46.1-57.2)$ & $47.2(33.6-61.3)$ \\
\hline Median (Range)** & & & $49.3(36.4-62.4)$ & $37.3(27.1-53.7)$ \\
\hline Guam & 192 & 5,000 & $39.1(29.7-49.4)$ & $26.8(19.2-36.1)$ \\
\hline Puerto Rico & 1,084 & 206,000 & $45.3(41.8-48.9)$ & $28.1(23.9-32.8)$ \\
\hline
\end{tabular}

Abbreviation: $\mathrm{Cl}=$ confidence interval.

* The numerator was the estimated number of adults with arthritis and diabetes. The denominator was the estimated number of adults with diabetes.

† Age standardized to the 2000 U.S. projected population, using three age groups: $18-44,45-64$, and $\geq 65$ years.

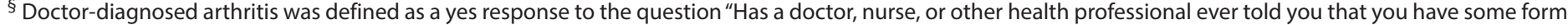
of arthritis, rheumatoid arthritis, gout, lupus, or fibromyalgia?"

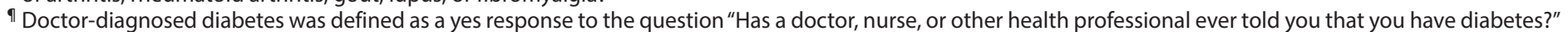
Those with prediabetes or borderline diabetes and women who had diabetes only during pregnancy were classified as not having diabetes.

** Median and range were calculated from estimates for the 50 states and the District of Columbia. 
TABLE 5. Unadjusted and age-standardized* percentages of $\geq 14$ physically unhealthy days ${ }^{\dagger}$ during the past 30 days among adults aged $\geq 18$ years with arthritis, ${ }^{\S}$ by area — Behavioral Risk Factor Surveillance System, United States, 2015

\begin{tabular}{|c|c|c|c|c|}
\hline Area & $\begin{array}{l}\text { Weighted population } \\
\text { with arthritis } \\
\text { (rounded to } 1,000 \text { s) }\end{array}$ & $\begin{array}{l}\text { Weighted population with arthritis } \\
\text { and } \geq 14 \text { physically unhealthy days } \\
\text { (rounded to } 1,000 \text { s) }\end{array}$ & $\begin{array}{l}\text { Unadjusted } \\
\%(95 \% \mathrm{Cl})\end{array}$ & $\begin{array}{c}\text { Age-standardized } \\
\%(95 \% \mathrm{Cl})\end{array}$ \\
\hline Alabama & $1,248,000$ & 365,000 & $30.5(28.3-32.7)$ & $30.6(27.2-34.2)$ \\
\hline Alaska & 117,000 & 23,000 & $21.3(17.9-25.2)$ & $16.9(13.4-21.2)$ \\
\hline Arizona & $1,222,000$ & 354,000 & $29.7(27.2-32.3)$ & $30.1(25.8-34.8)$ \\
\hline Arkansas & 672,000 & 208,000 & $32.3(29.0-35.8)$ & $35.7(29.8-42.1)$ \\
\hline California & $5,719,000$ & $1,383,000$ & $24.5(22.5-26.7)$ & $24.6(21.3-28.2)$ \\
\hline Colorado & 949,000 & 232,000 & $25.1(23.1-27.3)$ & $27.7(23.9-31.7)$ \\
\hline Connecticut & 690,000 & 157,000 & $23.4(21.5-25.5)$ & $25.1(21.3-29.2)$ \\
\hline Delaware & 207,000 & 48,000 & $23.9(21.0-27.0)$ & $24.8(19.9-30.5)$ \\
\hline District of Columbia & 101,000 & 25,000 & $25.6(21.2-30.6)$ & $23.0(15.3-33.1)$ \\
\hline Florida & $4,154,000$ & $1,190,000$ & $30.0(27.8-32.4)$ & $33.6(28.8-38.9)$ \\
\hline Georgia & $1,890,000$ & 526,000 & $28.7(25.8-31.8)$ & $25.0(20.7-29.9)$ \\
\hline Hawaii & 211,000 & 45,000 & $21.4(18.8-24.3)$ & $21.0(16.7-26.2)$ \\
\hline Idaho & 309,000 & 68,000 & $22.8(20.3-25.4)$ & $24.7(20.3-29.6)$ \\
\hline Illinois & $2,308,000$ & 595,000 & $26.0(23.2-28.9)$ & $24.8(19.9-30.4)$ \\
\hline Indiana & $1,390,000$ & 377,000 & $28.3(25.6-31.1)$ & $30.1(24.9-35.8)$ \\
\hline lowa & 619,000 & 131,000 & $21.9(19.7-24.2)$ & $20.4(16.6-24.7)$ \\
\hline Kansas & 536,000 & 119,000 & $23.0(21.8-24.2)$ & $22.9(20.9-25.1)$ \\
\hline Kentucky & $1,087,000$ & 338,000 & $31.9(29.4-34.5)$ & $30.2(26.2-34.5)$ \\
\hline Louisiana & 989,000 & 288,000 & $30.5(27.6-33.4)$ & $29.8(25.3-34.7)$ \\
\hline Maine & 332,000 & 82,000 & $25.2(23.1-27.5)$ & $29.1(24.9-33.7)$ \\
\hline Maryland & $1,096,000$ & 260,000 & $24.7(22.0-27.5)$ & $28.7(23.1-35.0)$ \\
\hline Massachusetts & $1,300,000$ & 325,000 & $26.1(23.8-28.6)$ & $29.0(25.0-33.3)$ \\
\hline Michigan & $2,305,000$ & 622,000 & $27.5(25.6-29.5)$ & $29.8(26.5-33.2)$ \\
\hline Minnesota & 907,000 & 218,000 & $24.8(23.1-26.5)$ & $27.1(23.7-30.6)$ \\
\hline Mississippi & 647,000 & 224,000 & $35.6(32.8-38.5)$ & $35.5(30.8-40.6)$ \\
\hline Missouri & $1,372,000$ & 390,000 & $29.1(26.7-31.7)$ & $29.3(24.9-34.0)$ \\
\hline Montana & 216,000 & 54,000 & $25.5(22.8-28.4)$ & $26.7(21.9-32.1)$ \\
\hline Nebraska & 334,000 & 70,000 & $21.3(19.7-23.0)$ & $20.3(17.5-23.4)$ \\
\hline Nevada & 477,000 & 126,000 & $27.5(22.9-32.5)$ & $30.6(22.6-40.0)$ \\
\hline New Hampshire & 282,000 & 64,000 & $23.1(20.9-25.6)$ & $25.5(20.9-30.8)$ \\
\hline New Jersey & $1,590,000$ & 378,000 & $24.8(22.5-27.1)$ & $24.4(20.9-28.3)$ \\
\hline New Mexico & 386,000 & 111,000 & $29.3(26.7-32.1)$ & $27.8(23.2-33.0)$ \\
\hline New York & $3,629,000$ & 910,000 & $26.5(24.5-28.6)$ & $30.0(26.0-34.2)$ \\
\hline North Carolina & $2,089,000$ & 607,000 & $30.2(27.7-32.7)$ & $27.8(24.2-31.6)$ \\
\hline North Dakota & 134,000 & 28,000 & $21.5(18.8-24.4)$ & $21.7(17.1-27.0)$ \\
\hline Ohio & $2,547,000$ & 664,000 & $26.8(24.6-29.1)$ & $27.0(22.8-31.6)$ \\
\hline Oklahoma & 813,000 & 278,000 & $35.2(32.5-38.0)$ & $37.5(32.7-42.6)$ \\
\hline Oregon & 838,000 & 238,000 & $29.6(26.9-32.5)$ & $30.2(25.8-35.0)$ \\
\hline Pennsylvania & $2,937,000$ & 682,000 & $23.8(21.5-26.4)$ & $24.4(20.4-28.8)$ \\
\hline Rhode Island & 226,000 & 61,000 & $28.4(25.6-31.3)$ & $32.7(27.1-38.9)$ \\
\hline South Carolina & $1,105,000$ & 332,000 & $31.1(29.2-33.2)$ & $31.3(27.8-35.0)$ \\
\hline South Dakota & 158,000 & 35,000 & $22.4(19.7-25.5)$ & $20.3(16.5-24.7)$ \\
\hline Tennessee & $1,630,000$ & 521,000 & $33.0(30.2-36.0)$ & $31.9(27.4-36.8)$ \\
\hline Texas & $4,055,000$ & $1,035,000$ & $26.7(24.2-29.3)$ & $25.9(22.0-30.3)$ \\
\hline Utah & 407,000 & 98,000 & $24.8(22.8-27.0)$ & $25.3(22.4-28.4)$ \\
\hline Vermont & 136,000 & 33,000 & $25.3(22.8-28.0)$ & $26.5(21.9-31.6)$ \\
\hline Virginia & $1,513,000$ & 359,000 & $24.3(22.1-26.6)$ & $24.5(20.6-28.8)$ \\
\hline Washington & $1,346,000$ & 332,000 & $25.2(23.5-26.9)$ & $27.7(24.3-31.3)$ \\
\hline West Virginia & 557,000 & 186,000 & $34.1(32.0-36.4)$ & $33.1(29.8-36.5)$ \\
\hline Wisconsin & $1,104,000$ & 264,000 & $24.2(21.7-27.0)$ & $21.1(17.6-25.0)$ \\
\hline Wyoming & 116,000 & 30,000 & $26.5(23.3-29.9)$ & $28.9(23.1-35.4)$ \\
\hline Median (Range)" & & & $26.0(21.3-35.6)$ & $27.7(16.9-37.5)$ \\
\hline Guam & 17,000 & 4,000 & $23.8(17.5-31.4)$ & $21.5(14.8-30.2)$ \\
\hline Puerto Rico & 635,000 & 196,000 & $31.0(28.3-33.8)$ & $30.6(25.8-35.9)$ \\
\hline
\end{tabular}

Abbreviation: $\mathrm{Cl}=$ confidence interval.

* Age standardized to the 2000 U.S. projected population, using three age groups: $18-44,45-64$, and $\geq 65$ years.

† Respondents with arthritis who answered 14-30 days to the question"Now thinking about your physical health, which includes physical illness and injury, for how many days during the past 30 days was your physical health not good?"

$\S$ Doctor-diagnosed arthritis was defined as a yes response to the question "Has a doctor, nurse, or other health professional ever told you that you have some form of arthritis, rheumatoid arthritis, gout, lupus, or fibromyalgia?"

" Median and range were calculated from estimates for the 50 states and the District of Columbia. 
TABLE 6. Unadjusted and age-standardized* percentages of $\geq 14$ mentally unhealthy days ${ }^{\dagger}$ during the past 30 days among adults aged $\geq 18$ years with arthritis, \$ by area — Behavioral Risk Factor Surveillance System, United States, 2015

\begin{tabular}{|c|c|c|c|c|}
\hline Area & $\begin{array}{l}\text { Weighted population } \\
\text { with arthritis } \\
\text { (rounded to } 1,000 \text { s) }\end{array}$ & $\begin{array}{l}\text { Weighted population with arthritis } \\
\text { and } \geq 14 \text { mentally unhealthy days } \\
\text { (rounded to } 1,000 \text { s) }\end{array}$ & $\begin{array}{l}\text { Unadjusted } \\
\%(95 \% \mathrm{CI})\end{array}$ & $\begin{array}{c}\text { Age-standardized } \\
\%(95 \% \mathrm{Cl})\end{array}$ \\
\hline Alabama & $1,248,000$ & 268,000 & $22.0(20.0-24.1)$ & $29.4(25.8-33.2)$ \\
\hline Alaska & 117,000 & 19,000 & $16.6(13.2-20.7)$ & $18.0(13.0-24.4)$ \\
\hline Arizona & $1,222,000$ & 210,000 & $17.5(15.5-19.7)$ & $21.0(17.3-25.4)$ \\
\hline Arkansas & 672,000 & 138,000 & $21.2(18.2-24.5)$ & $26.6(21.2-32.7)$ \\
\hline California & $5,719,000$ & 934,000 & $16.6(14.8-18.5)$ & $21.7(18.4-25.4)$ \\
\hline Colorado & 949,000 & 145,000 & $15.7(13.8-17.7)$ & $23.1(19.3-27.4)$ \\
\hline Connecticut & 690,000 & 104,000 & $15.3(13.7-17.0)$ & $21.1(17.7-25.0)$ \\
\hline Delaware & 207,000 & 36,000 & $17.5(15.0-20.4)$ & $20.1(15.4-25.7)$ \\
\hline District of Columbia & 101,000 & 17,000 & $17.5(13.5-22.3)$ & $20.1(12.4-31.0)$ \\
\hline Florida & $4,154,000$ & 772,000 & $19.0(17.1-21.2)$ & $23.9(20.0-28.3)$ \\
\hline Georgia & $1,890,000$ & 343,000 & $18.8(16.2-21.7)$ & $21.0(16.1-26.9)$ \\
\hline Hawaii & 211,000 & 24,000 & $11.7(9.7-13.9)$ & $14.8(10.9-19.9)$ \\
\hline Idaho & 309,000 & 46,000 & $15.3(13.0-17.9)$ & $22.2(17.5-27.7)$ \\
\hline Illinois & $2,308,000$ & 330,000 & $14.6(12.4-17.0)$ & $19.3(15.0-24.5)$ \\
\hline Indiana & $1,390,000$ & 241,000 & $17.8(15.5-20.4)$ & $24.4(19.4-30.2)$ \\
\hline lowa & 619,000 & 85,000 & $13.9(12.0-16.1)$ & $22.3(17.8-27.6)$ \\
\hline Kansas & 536,000 & 77,000 & $14.6(13.6-15.7)$ & $20.3(18.2-22.6)$ \\
\hline Kentucky & $1,087,000$ & 224,000 & $21.1(18.6-23.8)$ & $26.5(21.9-31.7)$ \\
\hline Louisiana & 989,000 & 199,000 & $20.6(18.2-23.3)$ & $25.6(21.2-30.6)$ \\
\hline Maine & 332,000 & 57,000 & $17.6(15.7-19.6)$ & $25.0(21.1-29.4)$ \\
\hline Maryland & $1,096,000$ & 204,000 & $19.0(16.5-21.9)$ & $29.9(24.2-36.2)$ \\
\hline Massachusetts & $1,300,000$ & 238,000 & $18.8(16.7-21.1)$ & $26.3(22.3-30.9)$ \\
\hline Michigan & $2,305,000$ & 408,000 & $18.0(16.3-19.8)$ & $24.0(20.9-27.4)$ \\
\hline Minnesota & 907,000 & 118,000 & $13.3(12.0-14.7)$ & $19.5(16.6-22.7)$ \\
\hline Mississippi & 647,000 & 148,000 & $23.6(21.0-26.4)$ & $31.1(26.3-36.3)$ \\
\hline Missouri & $1,372,000$ & 263,000 & $19.6(17.2-22.1)$ & $25.8(21.1-31.1)$ \\
\hline Montana & 216,000 & 34,000 & $16.0(13.6-18.7)$ & $21.8(16.9-27.7)$ \\
\hline Nebraska & 334,000 & 43,000 & $13.1(11.8-14.6)$ & $16.7(13.9-20.1)$ \\
\hline Nevada & 477,000 & 93,000 & $19.9(15.4-25.3)$ & $30.0(21.5-40.2)$ \\
\hline New Hampshire & 282,000 & 45,000 & $16.3(14.3-18.5)$ & $24.1(19.2-29.8)$ \\
\hline New Jersey & $1,590,000$ & 249,000 & $16.0(14.1-18.2)$ & $21.3(17.2-26.2)$ \\
\hline New Mexico & 386,000 & 65,000 & $17.2(15.0-19.7)$ & $21.6(17.2-26.8)$ \\
\hline New York & $3,629,000$ & 636,000 & $18.2(16.4-20.1)$ & $23.3(19.9-27.0)$ \\
\hline North Carolina & $2,089,000$ & 404,000 & $19.7(17.6-22.0)$ & $24.6(20.8-28.8)$ \\
\hline North Dakota & 134,000 & 17,000 & $13.3(10.7-16.4)$ & $21.7(16.2-28.3)$ \\
\hline Ohio & $2,547,000$ & 470,000 & $18.9(16.8-21.1)$ & $25.6(21.3-30.3)$ \\
\hline Oklahoma & 813,000 & 179,000 & $22.6(20.2-25.2)$ & $28.6(24.1-33.5)$ \\
\hline Oregon & 838,000 & 167,000 & $20.6(18.1-23.3)$ & $27.4(22.9-32.5)$ \\
\hline Pennsylvania & $2,937,000$ & 478,000 & $16.6(14.5-18.9)$ & $21.0(17.0-25.5)$ \\
\hline Rhode Island & 226,000 & 41,000 & $18.4(16.0-21.2)$ & $26.9(21.5-33.2)$ \\
\hline South Carolina & $1,105,000$ & 238,000 & $22.3(20.5-24.2)$ & $28.4(24.9-32.3)$ \\
\hline South Dakota & 158,000 & 18,000 & $11.3(9.2-13.9)$ & $15.7(11.6-21.1)$ \\
\hline Tennessee & $1,630,000$ & 337,000 & $21.0(18.6-23.7)$ & $25.8(21.3-30.8)$ \\
\hline Texas & $4,055,000$ & 658,000 & $16.7(14.6-19.1)$ & $23.2(18.8-28.3)$ \\
\hline Utah & 407,000 & 66,000 & $16.7(14.9-18.6)$ & $20.4(17.6-23.5)$ \\
\hline Vermont & 136,000 & 20,000 & $15.1(13.1-17.2)$ & $20.3(16.4-24.9)$ \\
\hline Virginia & $1,513,000$ & 207,000 & $14.0(12.2-15.9)$ & $19.7(16.2-23.8)$ \\
\hline Washington & $1,346,000$ & 211,000 & $15.9(14.5-17.4)$ & $20.8(17.9-24.1)$ \\
\hline West Virginia & 557,000 & 127,000 & $23.5(21.5-25.5)$ & $28.5(25.3-32.0)$ \\
\hline Wisconsin & $1,104,000$ & 173,000 & $15.8(13.5-18.4)$ & $22.0(17.2-27.6)$ \\
\hline Wyoming & 116,000 & 18,000 & $15.8(13.3-18.7)$ & $20.0(15.5-25.5)$ \\
\hline Median (Range)" & & & $17.5(11.3-23.6)$ & $22.3(14.8-31.1)$ \\
\hline Guam & 17,000 & 3,000 & $15.5(10.9-21.5)$ & $18.1(11.5-27.3)$ \\
\hline Puerto Rico & 635,000 & 144,000 & $23.0(20.5-25.6)$ & $27.7(22.9-33.0)$ \\
\hline
\end{tabular}

Abbreviation: $\mathrm{Cl}=$ confidence interval.

* Age standardized to the 2000 U.S. projected population, using three age groups: 18-44, 45-64, and $\geq 65$ years.

† Respondents with arthritis who answered 14-30 days to the question "Now thinking about your mental health, which includes stress, depression, and problems with emotions, for how many days during the past 30 days was your mental health not good?"

$\S$ Doctor-diagnosed arthritis was defined as a yes response to the question “Has a doctor, nurse, or other health professional ever told you that you have some form of arthritis, rheumatoid arthritis, gout, lupus, or fibromyalgia?"

"Median and range were calculated from estimates for the 50 states and the District of Columbia. 
TABLE 7. Unadjusted and age-standardized* percentages of physical inactivity ${ }^{\dagger}$ among adults aged $\geq 18$ years with arthritis, ${ }^{\S}$ by area Behavioral Risk Factor Surveillance System, United States, 2015

\begin{tabular}{|c|c|c|c|c|}
\hline Area & $\begin{array}{l}\text { Weighted population } \\
\text { with arthritis } \\
\text { (rounded to } 1,000 \mathrm{~s} \text { ) }\end{array}$ & $\begin{array}{l}\text { Weighted population with } \\
\text { arthritis and physical inactivity } \\
\text { (rounded to } 1,000 \text { s) }\end{array}$ & $\begin{array}{l}\text { Unadjusted } \\
\%(95 \% \mathrm{Cl})\end{array}$ & $\begin{array}{c}\text { Age-standardized } \\
\%(95 \% \mathrm{CI})\end{array}$ \\
\hline Alabama & $1,248,000$ & 488,000 & $43.7(41.2-46.2)$ & $40.0(36.2-44.0)$ \\
\hline Alaska & 117,000 & 33,000 & $31.8(27.1-36.9)$ & $30.8(24.1-38.5)$ \\
\hline Arizona & $1,222,000$ & 357,000 & $33.7(31.1-36.4)$ & $31.8(27.0-36.9)$ \\
\hline Arkansas & 672,000 & 280,000 & $47.6(43.8-51.5)$ & $44.3(38.0-50.8)$ \\
\hline California & $5,719,000$ & $1,217,000$ & $24.7(22.5-27.1)$ & $23.1(19.8-26.9)$ \\
\hline Colorado & 949,000 & 218,000 & $27.0(24.9-29.3)$ & $25.2(21.8-28.9)$ \\
\hline Connecticut & 690,000 & 195,000 & $32.5(30.4-34.7)$ & $26.7(23.4-30.2)$ \\
\hline Delaware & 207,000 & 78,000 & $41.8(38.2-45.5)$ & 37.5 (31.1-44.3) \\
\hline District of Columbia & 101,000 & 25,000 & $30.9(26.1-36.1)$ & $24.9(16.2-36.2)$ \\
\hline Florida & $4,154,000$ & $1,396,000$ & $39.1(36.6-41.7)$ & $36.6(31.3-42.2)$ \\
\hline Georgia & $1,890,000$ & 650,000 & $38.9(35.6-42.3)$ & 35.9 (29.6-42.6) \\
\hline Hawaii & 211,000 & 50,000 & $26.0(23.2-29.0)$ & $29.0(23.7-34.8)$ \\
\hline Idaho & 309,000 & 87,000 & $31.1(28.2-34.1)$ & $28.6(23.9-33.8)$ \\
\hline Illinois & $2,308,000$ & 768,000 & $36.4(33.4-39.5)$ & $33.4(28.1-39.0)$ \\
\hline Indiana & $1,390,000$ & 505,000 & $40.9(37.8-44.0)$ & $37.0(31.3-43.1)$ \\
\hline lowa & 619,000 & 205,000 & $37.5(34.7-40.3)$ & $38.5(33.0-44.3)$ \\
\hline Kansas & 536,000 & 173,000 & $36.9(35.5-38.3)$ & $33.0(30.6-35.5)$ \\
\hline Kentucky & $1,087,000$ & 423,000 & $44.1(41.2-47.0)$ & $39.9(35.4-44.7)$ \\
\hline Louisiana & 989,000 & 375,000 & $44.6(41.3-48.0)$ & $40.1(34.7-45.6)$ \\
\hline Maine & 332,000 & 111,000 & $36.9(34.5-39.2)$ & $36.0(31.7-40.5)$ \\
\hline Maryland & $1,096,000$ & 355,000 & $38.0(34.9-41.2)$ & $37.1(31.2-43.5)$ \\
\hline Massachusetts & $1,300,000$ & 408,000 & $37.7(34.9-40.5)$ & $36.0(31.3-41.0)$ \\
\hline Michigan & $2,305,000$ & 747,000 & 35.7 (33.5-37.9) & $34.0(30.5-37.7)$ \\
\hline Minnesota & 907,000 & 275,000 & $33.1(31.3-35.0)$ & $30.7(27.3-34.3)$ \\
\hline Mississippi & 647,000 & 297,000 & $50.1(47.0-53.1)$ & $47.9(42.7-53.1)$ \\
\hline Missouri & $1,372,000$ & 466,000 & $37.3(34.6-40.2)$ & 36.6 (31.6-41.9) \\
\hline Montana & 216,000 & 61,000 & $30.3(27.4-33.4)$ & $28.9(24.0-34.4)$ \\
\hline Nebraska & 334,000 & 104,000 & $34.0(32.1-36.0)$ & $28.5(25.2-32.2)$ \\
\hline Nevada & 477,000 & 140,000 & $33.0(27.9-38.5)$ & $31.0(23.1-40.1)$ \\
\hline New Hampshire & 282,000 & 87,000 & $35.0(32.3-37.7)$ & $33.0(27.7-38.8)$ \\
\hline New Jersey & $1,590,000$ & 523,000 & $37.1(34.4-39.8)$ & $32.8(28.4-37.4)$ \\
\hline New Mexico & 386,000 & 104,000 & $30.3(27.6-33.2)$ & $29.1(24.1-34.7)$ \\
\hline New York & $3,629,000$ & $1,241,000$ & $41.1(38.8-43.4)$ & $39.7(35.3-44.1)$ \\
\hline North Carolina & $2,089,000$ & 749,000 & $39.9(37.2-42.7)$ & $37.1(32.8-41.6)$ \\
\hline North Dakota & 134,000 & 45,000 & $37.4(34.1-40.7)$ & $35.1(29.3-41.4)$ \\
\hline Ohio & $2,547,000$ & 884,000 & $39.2(36.7-41.7)$ & $35.7(31.3-40.5)$ \\
\hline Oklahoma & 813,000 & 340,000 & $45.9(43.1-48.7)$ & $41.9(37.1-46.8)$ \\
\hline Oregon & 838,000 & 193,000 & $26.8(24.0-29.7)$ & $24.0(19.9-28.7)$ \\
\hline Pennsylvania & $2,937,000$ & $1,010,000$ & $39.2(36.3-42.3)$ & $38.0(32.9-43.4)$ \\
\hline Rhode Island & 226,000 & 75,000 & $38.5(35.5-41.7)$ & $36.8(30.5-43.6)$ \\
\hline South Carolina & $1,105,000$ & 373,000 & $37.6(35.5-39.7)$ & $35.0(31.4-38.7)$ \\
\hline South Dakota & 158,000 & 43,000 & $29.7(26.4-33.2)$ & $23.4(19.3-28.0)$ \\
\hline Tennessee & $1,630,000$ & 575,000 & $41.2(38.0-44.5)$ & 38.9 (33.7-44.3) \\
\hline Texas & $4,055,000$ & $1,519,000$ & $43.0(40.0-46.0)$ & $43.4(38.5-48.5)$ \\
\hline Utah & 407,000 & 106,000 & $29.4(27.2-31.6)$ & $28.0(24.8-31.4)$ \\
\hline Vermont & 136,000 & 40,000 & $32.1(29.4-35.0)$ & $31.0(26.4-36.1)$ \\
\hline Virginia & $1,513,000$ & 520,000 & $38.1(35.4-40.9)$ & 36.3 (31.9-40.9) \\
\hline Washington & $1,346,000$ & 317,000 & $26.3(24.6-28.0)$ & $25.8(22.6-29.4)$ \\
\hline West Virginia & 557,000 & 209,000 & $41.0(38.7-43.4)$ & $38.6(35.0-42.3)$ \\
\hline Wisconsin & $1,104,000$ & 281,000 & $29.0(26.2-32.1)$ & $24.6(19.9-30.0)$ \\
\hline Wyoming & 116,000 & 37,000 & $35.2(31.8-38.8)$ & $34.4(28.6-40.7)$ \\
\hline Median (Range)" & & & $37.1(24.7-50.1)$ & $35.0(23.1-47.9)$ \\
\hline Guam & 17,000 & 7,000 & $45.7(37.1-54.5)$ & $39.6(29.8-50.2)$ \\
\hline Puerto Rico & 635,000 & 371,000 & $60.5(57.5-63.5)$ & $58.1(52.1-63.8)$ \\
\hline
\end{tabular}

Abbreviation: $\mathrm{Cl}=$ confidence interval.

* Age standardized to the 2000 U.S. projected population, using three age groups: 18-44, 45-64, and $\geq 65$ years.

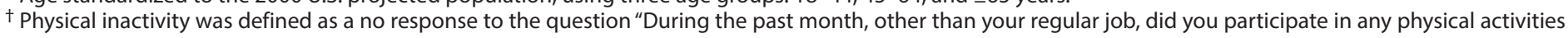
or exercises such as running, calisthenics, golf, gardening, or walking for exercise?"

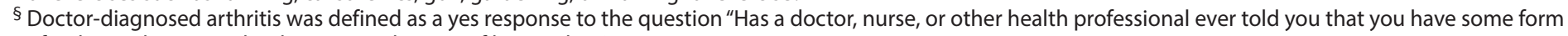
of arthritis, rheumatoid arthritis, gout, lupus, or fibromyalgia?"

" Median and range were calculated from estimates for the 50 states and the District of Columbia. 
TABLE 8. Unadjusted and age-standardized* percentages of walking ${ }^{\dagger}$ among adults aged $\geq 18$ years with arthritis, ${ }^{\S}$ by area - Behavioral Risk Factor Surveillance System, United States, 2015

\begin{tabular}{|c|c|c|c|c|}
\hline Area & $\begin{array}{l}\text { Weighted population } \\
\text { with arthritis } \\
\text { (rounded to } 1,000 \text { s) }\end{array}$ & $\begin{array}{l}\text { Weighted population with } \\
\text { arthritis and walking } \\
\text { (rounded to } 1,000 \text { s) }\end{array}$ & $\begin{array}{l}\text { Unadjusted } \\
\%(95 \% \mathrm{Cl})\end{array}$ & $\begin{array}{c}\text { Age-standardized } \\
\%(95 \% \mathrm{Cl})\end{array}$ \\
\hline Alabama & $1,248,000$ & 501,000 & $43.6(41.1-46.0)$ & $44.8(40.7-48.9)$ \\
\hline Alaska & 117,000 & 59,000 & $53.9(48.9-58.8)$ & $52.3(44.8-59.7)$ \\
\hline Arizona & $1,222,000$ & 570,000 & $51.5(48.7-54.3)$ & $50.8(45.3-56.2)$ \\
\hline Arkansas & 672,000 & 249,000 & $40.6(37.0-44.3)$ & 41.8 (35.4-48.4) \\
\hline California & $5,719,000$ & $2,996,000$ & $59.4(56.7-62.0)$ & $55.6(51.3-59.9)$ \\
\hline Colorado & 949,000 & 464,000 & $55.4(52.9-57.7)$ & $55.4(50.9-59.8)$ \\
\hline Connecticut & 690,000 & 308,000 & $49.4(47.2-51.7)$ & $51.5(47.1-55.9)$ \\
\hline Delaware & 207,000 & 83,000 & $42.9(39.4-46.4)$ & $43.1(36.5-49.9)$ \\
\hline District of Columbia & 101,000 & 50,000 & $53.6(48.2-59.0)$ & $51.9(40.2-63.5)$ \\
\hline Florida & $4,154,000$ & $1,751,000$ & $47.2(44.7-49.7)$ & $46.9(41.4-52.4)$ \\
\hline Georgia & $1,890,000$ & 829,000 & $47.7(44.4-51.1)$ & $45.2(38.8-51.7)$ \\
\hline Hawaii & 211,000 & 101,000 & $52.1(48.8-55.4)$ & $47.2(41.4-53.1)$ \\
\hline Idaho & 309,000 & 157,000 & $54.1(50.9-57.3)$ & $53.0(47.3-58.5)$ \\
\hline Illinois & $2,308,000$ & 949,000 & $44.6(41.5-47.7)$ & $45.7(39.9-51.6)$ \\
\hline Indiana & $1,390,000$ & 615,000 & $48.3(45.2-51.4)$ & $51.8(45.8-57.7)$ \\
\hline lowa & 619,000 & 268,000 & $47.2(44.4-50.1)$ & $43.5(38.1-49.0)$ \\
\hline Kansas & 536,000 & 230,000 & $47.4(46.0-48.9)$ & $48.9(46.2-51.5)$ \\
\hline Kentucky & $1,087,000$ & 426,000 & $42.9(40.0-45.8)$ & $46.2(41.2-51.2)$ \\
\hline Louisiana & 989,000 & 377,000 & $42.3(39.0-45.6)$ & $46.3(40.9-51.9)$ \\
\hline Maine & 332,000 & 158,000 & $50.7(48.2-53.1)$ & $51.0(46.2-55.7)$ \\
\hline Maryland & $1,096,000$ & 457,000 & $46.5(43.5-49.6)$ & $46.2(40.2-52.3)$ \\
\hline Massachusetts & $1,300,000$ & 539,000 & $46.9(44.1-49.7)$ & $43.4(38.9-48.0)$ \\
\hline Michigan & $2,305,000$ & $1,018,000$ & $46.8(44.6-49.0)$ & $45.7(42.1-49.3)$ \\
\hline Minnesota & 907,000 & 441,000 & $51.6(49.7-53.5)$ & $52.6(48.9-56.2)$ \\
\hline Mississippi & 647,000 & 248,000 & $40.2(37.4-43.1)$ & $40.3(35.3-45.5)$ \\
\hline Missouri & $1,372,000$ & 592,000 & $46.1(43.4-49.0)$ & $48.0(42.7-53.3)$ \\
\hline Montana & 216,000 & 120,000 & $57.9(54.8-60.9)$ & $59.5(53.8-64.9)$ \\
\hline Nebraska & 334,000 & 161,000 & $51.0(48.9-53.1)$ & $52.9(48.7-57.1)$ \\
\hline Nevada & 477,000 & 226,000 & $51.2(45.5-56.9)$ & $49.3(39.9-58.9)$ \\
\hline New Hampshire & 282,000 & 129,000 & $49.9(47.1-52.6)$ & $49.1(43.2-55.0)$ \\
\hline New Jersey & $1,590,000$ & 670,000 & $45.3(42.6-48.1)$ & $43.6(38.8-48.6)$ \\
\hline New Mexico & 386,000 & 185,000 & $52.5(49.4-55.6)$ & $52.4(46.3-58.4)$ \\
\hline New York & $3,629,000$ & $1,540,000$ & $48.3(46.1-50.6)$ & $47.3(43.0-51.6)$ \\
\hline North Carolina & $2,089,000$ & 892,000 & $45.2(42.5-47.9)$ & $45.6(41.1-50.2)$ \\
\hline North Dakota & 134,000 & 67,000 & $52.7(49.3-56.0)$ & $52.0(45.5-58.4)$ \\
\hline Ohio & $2,547,000$ & $1,068,000$ & $45.3(42.9-47.8)$ & $48.2(43.4-53.0)$ \\
\hline Oklahoma & 813,000 & 315,000 & $41.1(38.4-43.8)$ & $43.1(38.3-48.0)$ \\
\hline Oregon & 838,000 & 413,000 & $54.2(51.1-57.1)$ & 53.7 (48.5-58.9) \\
\hline Pennsylvania & $2,937,000$ & $1,234,000$ & $46.3(43.4-49.3)$ & $44.4(39.3-49.6)$ \\
\hline Rhode Island & 226,000 & 89,000 & $43.9(41.0-46.9)$ & $41.5(35.6-47.5)$ \\
\hline South Carolina & $1,105,000$ & 479,000 & $46.2(44.1-48.3)$ & $45.3(41.3-49.2)$ \\
\hline South Dakota & 158,000 & 80,000 & $53.6(50.0-57.2)$ & $54.5(47.9-61.0)$ \\
\hline Tennessee & $1,630,000$ & 680,000 & $46.3(43.2-49.5)$ & $46.4(41.1-51.8)$ \\
\hline Texas & $4,055,000$ & $1,651,000$ & $45.2(42.3-48.2)$ & $40.3(36.1-44.7)$ \\
\hline Utah & 407,000 & 201,000 & $53.6(51.3-56.0)$ & $53.1(49.6-56.7)$ \\
\hline Vermont & 136,000 & 69,000 & $53.3(50.4-56.1)$ & $53.5(48.3-58.6)$ \\
\hline Virginia & $1,513,000$ & 663,000 & $46.6(44.0-49.3)$ & $46.1(41.2-51.0)$ \\
\hline Washington & $1,346,000$ & 710,000 & $56.4(54.5-58.3)$ & $54.6(50.7-58.5)$ \\
\hline West Virginia & 557,000 & 208,000 & $39.0(36.8-41.3)$ & $38.5(35.0-42.1)$ \\
\hline Wisconsin & $1,104,000$ & 544,000 & $54.4(51.0-57.7)$ & $57.0(50.2-63.5)$ \\
\hline Wyoming & 116,000 & 54,000 & $50.2(46.7-53.8)$ & $50.0(43.8-56.3)$ \\
\hline Median (Range)" & & & $47.7(39.0-59.4)$ & $48.0(38.5-59.5)$ \\
\hline Guam & 17,000 & 6,000 & $36.3(28.6-44.7)$ & $34.0(23.5-46.3)$ \\
\hline Puerto Rico & 635,000 & 173,000 & $27.8(25.2-30.6)$ & $28.5(23.4-34.1)$ \\
\hline
\end{tabular}

Abbreviation: $\mathrm{Cl}=$ confidence interval.

* Age standardized to the 2000 U.S. projected population, using three age groups: $18-44,45-64$, and $\geq 65$ years.

† Respondents with arthritis who reported walking or hiking for one of two questions: 1 ) "What type of physical activity or exercise did you spend the most time doing during the past month?" and 2) "What other type of physical activity gave you the next most exercise during the past month?"The denominator included adults with arthritis who were either physically active or inactive.

$\S$ Doctor-diagnosed arthritis was defined as a yes response to the question "Has a doctor, nurse, or other health professional ever told you that you have some form of arthritis, rheumatoid arthritis, gout, lupus, or fibromyalgia?"

"Median and range were calculated from estimates for the 50 states and the District of Columbia. 
TABLE 9. Unadjusted and age-standardized* percentages of obesity ${ }^{\dagger}$ among adults aged $\geq 18$ years with arthritis, ${ }^{\S}$ by area - Behavioral Risk Factor Surveillance System, United States, 2015

\begin{tabular}{|c|c|c|c|c|}
\hline Area & $\begin{array}{l}\text { Weighted population } \\
\text { with arthritis } \\
\text { (rounded to } 1,000 \mathrm{~s} \text { ) }\end{array}$ & $\begin{array}{l}\text { Weighted population with } \\
\text { arthritis and obesity } \\
\text { (rounded to } 1,000 \text { s) }\end{array}$ & $\begin{array}{l}\text { Unadjusted } \\
\%(95 \% \mathrm{Cl})\end{array}$ & $\begin{array}{c}\text { Age-standardized } \\
\%(95 \% \mathrm{CI})\end{array}$ \\
\hline Alabama & $1,248,000$ & 512,000 & $43.8(41.4-46.2)$ & 45.9 (42.0-49.9) \\
\hline Alaska & 117,000 & 46,000 & $41.6(36.9-46.5)$ & $45.0(37.8-52.4)$ \\
\hline Arizona & $1,222,000$ & 398,000 & $35.6(33.0-38.4)$ & 34.6 (29.9-39.6) \\
\hline Arkansas & 672,000 & 275,000 & $44.2(40.5-47.9)$ & $48.9(42.5-55.4)$ \\
\hline California & $5,719,000$ & $1,749,000$ & $33.0(30.6-35.6)$ & 33.7 (29.8-37.9) \\
\hline Colorado & 949,000 & 250,000 & $28.9(26.8-31.1)$ & $28.1(24.7-31.9)$ \\
\hline Connecticut & 690,000 & 228,000 & 35.7 (33.6-37.9) & $37.3(33.2-41.6)$ \\
\hline Delaware & 207,000 & 70,000 & $37.5(34.1-41.0)$ & $38.4(32.1-45.1)$ \\
\hline District of Columbia & 101,000 & 41,000 & $43.9(38.5-49.5)$ & $42.4(30.7-55.0)$ \\
\hline Florida & $4,154,000$ & $1,381,000$ & $36.0(33.6-38.5)$ & $38.4(33.2-43.8)$ \\
\hline Georgia & $1,890,000$ & 759,000 & $42.2(38.9-45.5)$ & $38.0(32.6-43.8)$ \\
\hline Hawaii & 211,000 & 67,000 & $32.5(29.5-35.8)$ & $42.2(36.6-48.0)$ \\
\hline Idaho & 309,000 & 105,000 & 36.4 (33.3-39.6) & $37.3(32.1-42.8)$ \\
\hline Illinois & $2,308,000$ & 946,000 & $42.1(39.0-45.2)$ & $41.8(36.2-47.6)$ \\
\hline Indiana & $1,390,000$ & 537,000 & 41.7 (38.7-44.7) & $44.1(38.3-50.1)$ \\
\hline lowa & 619,000 & 241,000 & $42.2(39.4-45.0)$ & $44.7(39.3-50.3)$ \\
\hline Kansas & 536,000 & 194,000 & $41.1(39.7-42.6)$ & $43.2(40.6-45.9)$ \\
\hline Kentucky & $1,087,000$ & 457,000 & $44.9(42.0-47.9)$ & $48.5(43.5-53.5)$ \\
\hline Louisiana & 989,000 & 419,000 & $45.3(42.0-48.6)$ & $48.5(43.2-53.9)$ \\
\hline Maine & 332,000 & 122,000 & $38.7(36.3-41.1)$ & $42.3(37.7-47.0)$ \\
\hline Maryland & $1,096,000$ & 448,000 & 44.4 (41.2-47.6) & $47.9(41.8-54.1)$ \\
\hline Massachusetts & $1,300,000$ & 422,000 & $36.1(33.4-38.9)$ & $35.8(31.5-40.3)$ \\
\hline Michigan & $2,305,000$ & 875,000 & $40.4(38.2-42.6)$ & $42.1(38.6-45.8)$ \\
\hline Minnesota & 907,000 & 321,000 & $38.3(36.5-40.2)$ & $40.3(36.6-44.0)$ \\
\hline Mississippi & 647,000 & 260,000 & $42.0(39.1-44.9)$ & $44.3(39.2-49.5)$ \\
\hline Missouri & $1,372,000$ & 518,000 & $40.7(38.0-43.5)$ & $42.9(37.8-48.2)$ \\
\hline Montana & 216,000 & 62,000 & $31.1(28.3-34.1)$ & $29.6(24.8-34.8)$ \\
\hline Nebraska & 334,000 & 134,000 & $42.6(40.6-44.7)$ & $45.1(40.9-49.2)$ \\
\hline Nevada & 477,000 & 155,000 & 34.4 (29.2-39.9) & $35.2(26.7-44.7)$ \\
\hline New Hampshire & 282,000 & 94,000 & $36.9(34.3-39.6)$ & $40.7(35.0-46.6)$ \\
\hline New Jersey & $1,590,000$ & 539,000 & $37.3(34.6-40.1)$ & 38.7 (34.1-43.6) \\
\hline New Mexico & 386,000 & 127,000 & $35.2(32.2-38.3)$ & $43.1(37.3-49.1)$ \\
\hline New York & $3,629,000$ & $1,221,000$ & $36.4(34.2-38.6)$ & $40.1(36.0-44.4)$ \\
\hline North Carolina & $2,089,000$ & 780,000 & $40.0(37.3-42.7)$ & $41.4(37.0-46.0)$ \\
\hline North Dakota & 134,000 & 51,000 & $41.3(38.1-44.7)$ & $39.7(34.1-45.6)$ \\
\hline Ohio & $2,547,000$ & 947,000 & $40.2(37.8-42.7)$ & $40.4(35.7-45.2)$ \\
\hline Oklahoma & 813,000 & 329,000 & $42.9(40.2-45.7)$ & $44.9(40.1-49.8)$ \\
\hline Oregon & 838,000 & 302,000 & $39.3(36.4-42.4)$ & $41.6(36.6-46.8)$ \\
\hline Pennsylvania & $2,937,000$ & $1,114,000$ & $40.8(37.9-43.7)$ & $43.3(38.2-48.5)$ \\
\hline Rhode Island & 226,000 & 74,000 & $35.1(32.2-38.1)$ & $34.7(29.1-40.7)$ \\
\hline South Carolina & $1,105,000$ & 437,000 & $42.0(39.9-44.1)$ & $46.4(42.6-50.3)$ \\
\hline South Dakota & 158,000 & 60,000 & $40.4(36.9-44.0)$ & $41.8(35.3-48.5)$ \\
\hline Tennessee & $1,630,000$ & 640,000 & $42.3(39.2-45.5)$ & $46.5(41.3-51.8)$ \\
\hline Texas & $4,055,000$ & $1,518,000$ & $41.0(38.1-43.9)$ & $37.6(33.4-42.0)$ \\
\hline Utah & 407,000 & 137,000 & $36.2(33.9-38.5)$ & $36.2(32.9-39.6)$ \\
\hline Vermont & 136,000 & 43,000 & $34.2(31.5-36.9)$ & $35.7(30.8-40.9)$ \\
\hline Virginia & $1,513,000$ & 584,000 & $41.1(38.4-43.9)$ & $44.0(39.2-48.9)$ \\
\hline Washington & $1,346,000$ & 454,000 & $36.9(35.0-38.8)$ & 36.5 (33.0-40.3) \\
\hline West Virginia & 557,000 & 223,000 & $43.7(41.4-46.1)$ & $45.6(41.9-49.3)$ \\
\hline Wisconsin & $1,104,000$ & 417,000 & $40.2(37.0-43.5)$ & $41.0(34.9-47.4)$ \\
\hline Wyoming & 116,000 & 41,000 & $37.6(34.2-41.1)$ & $36.1(30.6-42.0)$ \\
\hline Median (Range)" & & & $40.2(28.9-45.3)$ & $41.6(28.1-48.9)$ \\
\hline Guam & 17,000 & 7,000 & $39.3(31.5-47.6)$ & $42.6(31.9-54.1)$ \\
\hline Puerto Rico & 635,000 & 215,000 & $35.6(32.6-38.6)$ & $41.1(35.3-47.2)$ \\
\hline
\end{tabular}

Abbreviation: $\mathrm{Cl}=$ confidence interval.

* Age standardized to the 2000 U.S. projected population, using three age groups: 18-44, 45-64, and $\geq 65$ years.

$\dagger$ Body mass index $\geq 30$; calculated from self-reported height and weight.

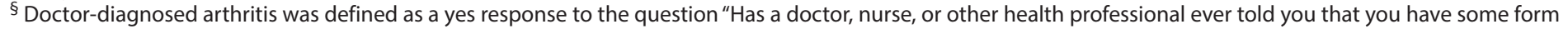
of arthritis, rheumatoid arthritis, gout, lupus, or fibromyalgia?"

" Median and range were calculated from estimates for the 50 states and the District of Columbia. 
TABLE 10. Unadjusted and age-standardized* percentages of arthritis-attributable activity limitations ${ }^{\dagger}$ among adults aged $\geq 18$ years with arthritis, $^{\S}$ by area - Behavioral Risk Factor Surveillance System, United States, 2015

\begin{tabular}{|c|c|c|c|c|}
\hline Area & $\begin{array}{l}\text { Weighted population } \\
\text { with arthritis } \\
\text { (rounded to } 1,000 \text { s) }\end{array}$ & $\begin{array}{l}\text { Weighted population with arthritis } \\
\text { and arthritis-attributable activity } \\
\text { limitations (rounded to } 1,000 \text { s) }\end{array}$ & $\begin{array}{l}\text { Unadjusted } \\
\%(95 \% \mathrm{Cl})\end{array}$ & $\begin{array}{c}\text { Age-standardized } \\
\%(95 \% \mathrm{Cl})\end{array}$ \\
\hline Alabama & $1,248,000$ & 640,000 & $56.7(54.3-59.1)$ & $59.2(55.2-63.0)$ \\
\hline Alaska & 117,000 & 55,000 & $51.2(46.2-56.1)$ & $51.1(43.6-58.6)$ \\
\hline Arizona & $1,222,000$ & 558,000 & $52.1(49.3-54.9)$ & $52.5(46.9-58.0)$ \\
\hline Arkansas & 672,000 & 345,000 & $57.0(53.2-60.7)$ & $56.1(49.4-62.5)$ \\
\hline California & $5,719,000$ & $2,446,000$ & $49.6(46.9-52.3)$ & $48.6(44.2-52.9)$ \\
\hline Colorado & 949,000 & 398,000 & $48.4(46.0-50.8)$ & $47.6(43.1-52.1)$ \\
\hline Connecticut & 690,000 & 290,000 & $47.6(45.3-49.8)$ & $46.7(42.3-51.2)$ \\
\hline Delaware & 207,000 & 90,000 & $47.1(43.5-50.8)$ & $46.9(39.9-54.0)$ \\
\hline District of Columbia & 101,000 & 48,000 & $53.9(48.4-59.3)$ & $57.0(45.0-68.2)$ \\
\hline Florida & $4,154,000$ & $1,941,000$ & $53.1(50.6-55.6)$ & $54.5(48.9-59.9)$ \\
\hline Georgia & $1,890,000$ & 882,000 & $51.9(48.4-55.3)$ & $50.9(44.1-57.6)$ \\
\hline Hawaii & 211,000 & 81,000 & $42.2(39.0-45.5)$ & $42.0(36.2-48.0)$ \\
\hline Idaho & 309,000 & 137,000 & $48.0(44.8-51.2)$ & $50.4(44.8-56.0)$ \\
\hline Illinois & $2,308,000$ & 982,000 & 46.5 (43.3-49.6) & $46.3(40.5-52.2)$ \\
\hline Indiana & $1,390,000$ & 599,000 & $47.7(44.6-50.8)$ & $43.7(38.1-49.5)$ \\
\hline lowa & 619,000 & 228,000 & $40.8(38.1-43.6)$ & $40.4(34.9-46.0)$ \\
\hline Kansas & 536,000 & 228,000 & $48.2(46.7-49.7)$ & $46.3(43.7-49.0)$ \\
\hline Kentucky & $1,087,000$ & 562,000 & $57.2(54.3-60.0)$ & $57.7(52.7-62.6)$ \\
\hline Louisiana & 989,000 & 472,000 & $53.9(50.6-57.2)$ & $50.6(45.0-56.1)$ \\
\hline Maine & 332,000 & 149,000 & $48.5(46.0-50.9)$ & $51.2(46.4-56.0)$ \\
\hline Maryland & $1,096,000$ & 405,000 & $42.2(39.2-45.2)$ & $42.2(36.3-48.4)$ \\
\hline Massachusetts & $1,300,000$ & 555,000 & $49.0(46.2-51.9)$ & $47.0(42.2-51.9)$ \\
\hline Michigan & $2,305,000$ & $1,038,000$ & $48.8(46.6-51.1)$ & $50.3(46.5-54.0)$ \\
\hline Minnesota & 907,000 & 393,000 & $46.7(44.8-48.5)$ & $47.0(43.3-50.6)$ \\
\hline Mississippi & 647,000 & 346,000 & $56.7(53.7-59.6)$ & $52.4(47.2-57.4)$ \\
\hline Missouri & $1,372,000$ & 694,000 & $54.6(51.8-57.4)$ & $59.4(54.5-64.1)$ \\
\hline Montana & 216,000 & 103,000 & $50.2(47.0-53.4)$ & $52.0(46.3-57.8)$ \\
\hline Nebraska & 334,000 & 137,000 & $44.0(41.9-46.1)$ & $44.3(40.1-48.6)$ \\
\hline Nevada & 477,000 & 212,000 & $48.7(43.0-54.5)$ & $53.3(44.2-62.3)$ \\
\hline New Hampshire & 282,000 & 115,000 & $45.6(42.8-48.3)$ & $49.9(43.8-55.9)$ \\
\hline New Jersey & $1,590,000$ & 675,000 & $46.5(43.8-49.3)$ & $47.0(42.0-52.2)$ \\
\hline New Mexico & 386,000 & 176,000 & $50.5(47.4-53.6)$ & $49.2(43.1-55.4)$ \\
\hline New York & $3,629,000$ & $1,503,000$ & $48.3(46.0-50.6)$ & $45.5(41.2-49.9)$ \\
\hline North Carolina & $2,089,000$ & $1,080,000$ & $55.6(52.9-58.3)$ & $54.5(49.9-59.0)$ \\
\hline North Dakota & 134,000 & 57,000 & $46.3(42.9-49.6)$ & $47.2(40.5-53.9)$ \\
\hline Ohio & $2,547,000$ & $1,136,000$ & $49.1(46.6-51.6)$ & $46.6(42.0-51.3)$ \\
\hline Oklahoma & 813,000 & 419,000 & $55.9(53.2-58.7)$ & $56.9(51.9-61.7)$ \\
\hline Oregon & 838,000 & 425,000 & $57.1(54.1-60.1)$ & $54.0(48.8-59.2)$ \\
\hline Pennsylvania & $2,937,000$ & $1,118,000$ & $42.7(39.8-45.7)$ & $42.1(37.0-47.4)$ \\
\hline Rhode Island & 226,000 & 89,000 & $45.1(42.0-48.2)$ & $44.1(37.6-50.7)$ \\
\hline South Carolina & $1,105,000$ & 555,000 & $54.8(52.7-56.9)$ & $54.4(50.3-58.4)$ \\
\hline South Dakota & 158,000 & 73,000 & $48.7(45.1-52.4)$ & $49.5(42.7-56.3)$ \\
\hline Tennessee & $1,630,000$ & 772,000 & $53.8(50.6-57.0)$ & $55.2(49.8-60.5)$ \\
\hline Texas & $4,055,000$ & $1,773,000$ & $50.0(47.0-53.0)$ & $48.2(43.3-53.1)$ \\
\hline Utah & 407,000 & 168,000 & $45.5(43.1-47.8)$ & $44.2(40.8-47.8)$ \\
\hline Vermont & 136,000 & 61,000 & $49.0(46.2-51.9)$ & $48.6(43.4-53.8)$ \\
\hline Virginia & $1,513,000$ & 631,000 & $44.8(42.2-47.5)$ & $46.7(41.9-51.6)$ \\
\hline Washington & $1,346,000$ & 657,000 & $53.3(51.4-55.2)$ & $50.6(46.6-54.5)$ \\
\hline West Virginia & 557,000 & 303,000 & $57.3(55.0-59.6)$ & $57.5(53.8-61.2)$ \\
\hline Wisconsin & $1,104,000$ & 479,000 & $49.2(45.9-52.7)$ & $50.9(44.1-57.7)$ \\
\hline Wyoming & 116,000 & 49,000 & $46.6(43.0-50.3)$ & $49.7(43.4-55.9)$ \\
\hline Median (Range)" & & & $49.0(40.8-57.3)$ & $49.7(40.4-59.4)$ \\
\hline Guam & 17,000 & 7,000 & $43.5(35.4-52.0)$ & $44.6(33.4-56.3)$ \\
\hline Puerto Rico & 635,000 & 353,000 & $57.0(54.0-60.0)$ & $60.8(54.9-66.4)$ \\
\hline
\end{tabular}

Abbreviation: $\mathrm{Cl}=$ confidence interval.

* Age standardized to the 2000 U.S. projected population, using three age groups: $18-44,45-64$, and $\geq 65$ years.

+ Respondents with arthritis who answered yes to the question "Arthritis can cause symptoms like pain, aching, or stiffness in or around the joint. Are you now limited in any way in any of your usual activities because of arthritis or joint symptoms?"

$\S$ Doctor-diagnosed arthritis was defined as a yes response to the question "Has a doctor, nurse, or other health professional ever told you that you have some form of arthritis, rheumatoid arthritis, gout, lupus, or fibromyalgia?"

" Median and range were calculated from estimates for the 50 states and the District of Columbia. 
TABLE 11. Unadjusted and age-standardized* percentages of arthritis-attributable social participation restriction ${ }^{\dagger}$ among adults aged $\geq 18$ years with arthritis, $\$$ by area — Behavioral Risk Factor Surveillance System, United States, 2015

\begin{tabular}{|c|c|c|c|c|}
\hline Area & $\begin{array}{l}\text { Weighted population } \\
\text { with arthritis } \\
\text { (rounded to } 1,000 \mathrm{~s} \text { ) }\end{array}$ & $\begin{array}{l}\text { Weighted population with arthritis } \\
\text { and arthritis-attributable social } \\
\text { participation restriction } \\
\text { (rounded to } 1,000 \text { s) }\end{array}$ & $\begin{array}{l}\text { Unadjusted } \\
\%(95 \% \mathrm{Cl})\end{array}$ & $\begin{array}{c}\text { Age-standardized } \\
\%(95 \% \mathrm{Cl})\end{array}$ \\
\hline Alabama & $1,248,000$ & 321,000 & $28.5(26.3-30.9)$ & $29.3(25.8-33.0)$ \\
\hline Alaska & 117,000 & 16,000 & $14.4(11.3-18.3)$ & $12.6(9.3-16.9)$ \\
\hline Arizona & $1,222,000$ & 212,000 & $19.7(17.6-22.0)$ & $18.1(14.8-22.1)$ \\
\hline Arkansas & 672,000 & 165,000 & $27.3(24.1-30.9)$ & $30.4(24.5-37.0)$ \\
\hline California & $5,719,000$ & 859,000 & $17.4(15.6-19.4)$ & $17.6(14.6-21.0)$ \\
\hline Colorado & 949,000 & 128,000 & $15.5(13.7-17.4)$ & $16.4(13.4-20.1)$ \\
\hline Connecticut & 690,000 & 97,000 & $15.9(14.2-17.8)$ & $14.5(12.1-17.4)$ \\
\hline Delaware & 207,000 & 35,000 & $18.5(15.7-21.6)$ & $18.8(13.4-25.8)$ \\
\hline District of Columbia & 101,000 & 22,000 & $25.2(20.4-30.7)$ & $26.8(17.4-38.8)$ \\
\hline Florida & $4,154,000$ & 843,000 & $23.3(21.1-25.6)$ & $25.7(21.0-31.1)$ \\
\hline Georgia & $1,890,000$ & 378,000 & $22.3(19.5-25.3)$ & $19.8(15.3-25.3)$ \\
\hline Hawaii & 211,000 & 26,000 & $13.4(11.1-16.0)$ & $15.9(11.4-21.7)$ \\
\hline Idaho & 309,000 & 53,000 & $18.7(16.2-21.6)$ & $22.4(17.7-28.0)$ \\
\hline Illinois & $2,308,000$ & 365,000 & $17.4(15.0-20.1)$ & $15.0(11.7-19.0)$ \\
\hline Indiana & $1,390,000$ & 237,000 & $18.8(16.6-21.4)$ & $20.0(15.7-25.2)$ \\
\hline lowa & 619,000 & 83,000 & $14.9(13.0-17.0)$ & $15.3(11.6-19.9)$ \\
\hline Kansas & 536,000 & 84,000 & $17.6(16.5-18.8)$ & $17.6(15.7-19.6)$ \\
\hline Kentucky & $1,087,000$ & 265,000 & $27.1(24.6-29.9)$ & $28.3(23.6-33.6)$ \\
\hline Louisiana & 989,000 & 234,000 & $26.8(23.9-29.8)$ & $25.5(20.8-30.7)$ \\
\hline Maine & 332,000 & 52,000 & $16.9(15.1-18.9)$ & $21.4(17.5-25.9)$ \\
\hline Maryland & $1,096,000$ & 160,000 & $16.6(14.4-19.0)$ & $19.7(14.9-25.7)$ \\
\hline Massachusetts & $1,300,000$ & 206,000 & $18.2(16.1-20.6)$ & $20.0(16.2-24.5)$ \\
\hline Michigan & $2,305,000$ & 420,000 & $19.6(17.8-21.5)$ & $19.6(16.8-22.7)$ \\
\hline Minnesota & 907,000 & 136,000 & $16.1(14.7-17.7)$ & $18.5(15.5-22.0)$ \\
\hline Mississippi & 647,000 & 172,000 & $28.5(25.8-31.3)$ & $26.0(22.1-30.4)$ \\
\hline Missouri & $1,372,000$ & 255,000 & $20.2(18.0-22.5)$ & $23.4(19.2-28.3)$ \\
\hline Montana & 216,000 & 33,000 & $16.2(13.8-18.8)$ & $18.6(14.2-24.0)$ \\
\hline Nebraska & 334,000 & 46,000 & $14.6(13.2-16.2)$ & $12.9(10.7-15.6)$ \\
\hline Nevada & 477,000 & 98,000 & $22.7(17.9-28.3)$ & $26.0(17.6-36.6)$ \\
\hline New Hampshire & 282,000 & 40,000 & $15.7(13.8-17.9)$ & $20.2(15.6-25.8)$ \\
\hline New Jersey & $1,590,000$ & 241,000 & $16.8(14.9-18.9)$ & $18.5(15.2-22.3)$ \\
\hline New Mexico & 386,000 & 71,000 & $20.6(18.1-23.2)$ & $21.0(16.5-26.4)$ \\
\hline New York & $3,629,000$ & 587,000 & $19.0(17.2-20.9)$ & $19.8(16.4-23.7)$ \\
\hline North Carolina & $2,089,000$ & 488,000 & $25.0(22.7-27.6)$ & $23.7(20.1-27.6)$ \\
\hline North Dakota & 134,000 & 18,000 & $14.7(12.5-17.3)$ & $14.8(10.8-19.9)$ \\
\hline Ohio & $2,547,000$ & 486,000 & $21.1(19.1-23.2)$ & $19.7(16.6-23.2)$ \\
\hline Oklahoma & 813,000 & 207,000 & $27.5(24.9-30.3)$ & $29.9(25.4-34.7)$ \\
\hline Oregon & 838,000 & 142,000 & $19.0(16.6-21.6)$ & $19.4(15.7-23.7)$ \\
\hline Pennsylvania & $2,937,000$ & 419,000 & $16.0(13.9-18.4)$ & $16.8(13.0-21.3)$ \\
\hline Rhode Island & 226,000 & 39,000 & $20.0(17.4-22.9)$ & $25.8(20.0-32.6)$ \\
\hline South Carolina & $1,105,000$ & 245,000 & $24.2(22.4-26.1)$ & $23.8(20.5-27.5)$ \\
\hline South Dakota & 158,000 & 20,000 & $13.7(11.3-16.5)$ & $14.4(9.5-21.1)$ \\
\hline Tennessee & $1,630,000$ & 372,000 & $26.0(23.2-28.9)$ & $24.7(20.3-29.6)$ \\
\hline Texas & $4,055,000$ & 739,000 & $20.8(18.5-23.3)$ & $20.7(16.9-25.2)$ \\
\hline Utah & 407,000 & 58,000 & $15.6(13.9-17.4)$ & $16.0(13.6-18.8)$ \\
\hline Vermont & 136,000 & 21,000 & $16.3(14.1-18.7)$ & $18.9(14.9-23.6)$ \\
\hline Virginia & $1,513,000$ & 251,000 & $17.8(16.0-19.8)$ & $18.1(14.9-21.9)$ \\
\hline Washington & $1,346,000$ & 221,000 & $17.8(16.3-19.4)$ & $18.0(15.3-21.0)$ \\
\hline West Virginia & 557,000 & 140,000 & $26.7(24.6-28.9)$ & $26.6(23.5-30.0)$ \\
\hline Wisconsin & $1,104,000$ & 153,000 & $15.9(13.6-18.4)$ & $16.6(12.8-21.1)$ \\
\hline Wyoming & 116,000 & 19,000 & $17.2(14.3-20.6)$ & $19.3(14.1-25.8)$ \\
\hline Median (Range)" & & & $18.5(13.4-28.5)$ & $19.7(12.6-30.4)$ \\
\hline Guam & 17,000 & 2,000 & $12.7(8.5-18.4)$ & 13.1 (7.7-21.5) \\
\hline Puerto Rico & 635,000 & 144,000 & $23.2(20.8-25.9)$ & $25.9(21.2-31.2)$ \\
\hline
\end{tabular}

Abbreviation: $\mathrm{Cl}=$ confidence interval.

* Age standardized to the 2000 U.S. projected population, using three age groups: $18-44,45-64$, and $\geq 65$ years.

† Respondents with arthritis who answered a lot to the question "During the past 30 days, to what extent has your arthritis or joint symptoms interfered with your normal social activities, such as going shopping, to the movies, or to religious or social gatherings?"

$\S$ Doctor-diagnosed arthritis was defined as a yes response to the question "Has a doctor, nurse, or other health professional ever told you that you have some form of arthritis, rheumatoid arthritis, gout, lupus, or fibromyalgia?"

"Median and range were calculated from estimates for the 50 states and the District of Columbia. 
TABLE 12. Unadjusted and age-standardized* percentages of arthritis-attributable severe joint pain ${ }^{\dagger}$ among adults aged $\geq 18$ years with arthritis, $\$$ by area — Behavioral Risk Factor Surveillance System, United States, 2015

\begin{tabular}{|c|c|c|c|c|}
\hline Area & $\begin{array}{l}\text { Weighted population } \\
\text { with arthritis } \\
\text { (rounded to } 1,000 \mathrm{~s} \text { ) }\end{array}$ & $\begin{array}{l}\text { Weighted population with arthritis } \\
\text { and arthritis-attributable severe } \\
\text { joint pain (rounded to } 1,000 \mathrm{~s} \text { ) }\end{array}$ & $\begin{array}{l}\text { Unadjusted } \\
\%(95 \% \mathrm{Cl})\end{array}$ & $\begin{array}{c}\text { Age-standardized } \\
\%(95 \% \mathrm{CI})\end{array}$ \\
\hline Alabama & $1,248,000$ & 433,000 & $39.2(36.8-41.6)$ & 39.7 (35.7-43.8) \\
\hline Alaska & 117,000 & - & -9 & - \\
\hline Arizona & $1,222,000$ & 328,000 & $30.6(28.0-33.3)$ & $32.9(28.0-38.2)$ \\
\hline Arkansas & 672,000 & 218,000 & $36.3(32.6-40.1)$ & $41.6(35.3-48.3)$ \\
\hline California & $5,719,000$ & $1,510,000$ & $30.2(27.9-32.7)$ & $29.3(25.8-33.0)$ \\
\hline Colorado & 949,000 & 194,000 & $24.0(21.9-26.2)$ & $26.2(22.3-30.4)$ \\
\hline Connecticut & 690,000 & 153,000 & $25.3(23.3-27.4)$ & $25.9(22.3-29.8)$ \\
\hline Delaware & 207,000 & 57,000 & $30.8(27.3-34.4)$ & $31.6(25.2-38.7)$ \\
\hline District of Columbia & 101,000 & 36,000 & $40.5(35.0-46.3)$ & 36.5 (26.5-47.9) \\
\hline Florida & $4,154,000$ & $1,195,000$ & $34.0(31.5-36.6)$ & $38.0(32.7-43.7)$ \\
\hline Georgia & $1,890,000$ & 573,000 & $34.1(30.8-37.4)$ & $31.2(25.7-37.4)$ \\
\hline Hawaii & 211,000 & 41,000 & $21.7(19.0-24.7)$ & $23.6(18.9-29.2)$ \\
\hline Idaho & 309,000 & 59,000 & $21.8(19.1-24.9)$ & $21.9(17.4-27.3)$ \\
\hline Illinois & $2,308,000$ & 576,000 & $27.4(24.6-30.5)$ & $24.4(20.2-29.3)$ \\
\hline Indiana & $1,390,000$ & 302,000 & $25.5(22.8-28.4)$ & $26.0(20.6-32.2)$ \\
\hline lowa & 619,000 & 122,000 & $22.3(20.0-24.8)$ & $24.3(19.7-29.6)$ \\
\hline Kansas & 536,000 & 121,000 & $25.7(24.4-27.1)$ & $26.2(23.8-28.6)$ \\
\hline Kentucky & $1,087,000$ & 349,000 & $36.3(33.5-39.1)$ & $36.7(32.0-41.7)$ \\
\hline Louisiana & 989,000 & 356,000 & $41.1(37.8-44.4)$ & $41.2(35.8-46.9)$ \\
\hline Maine & 332,000 & 69,000 & $23.9(21.6-26.3)$ & $30.3(25.6-35.4)$ \\
\hline Maryland & $1,096,000$ & 249,000 & $26.1(23.3-29.1)$ & $28.5(22.8-35.0)$ \\
\hline Massachusetts & $1,300,000$ & 310,000 & $28.0(25.4-30.8)$ & $28.4(24.1-33.2)$ \\
\hline Michigan & $2,305,000$ & 605,000 & $28.7(26.7-30.8)$ & $30.5(27.1-34.1)$ \\
\hline Minnesota & 907,000 & 181,000 & $21.8(20.1-23.5)$ & $23.3(19.9-27.1)$ \\
\hline Mississippi & 647,000 & 270,000 & $45.5(42.5-48.5)$ & $46.0(40.8-51.3)$ \\
\hline Missouri & $1,372,000$ & 375,000 & $30.1(27.6-32.8)$ & $34.0(29.2-39.2)$ \\
\hline Montana & 216,000 & 47,000 & $23.2(20.5-26.1)$ & $24.3(19.7-29.6)$ \\
\hline Nebraska & 334,000 & 67,000 & $21.6(19.9-23.5)$ & $22.8(19.4-26.6)$ \\
\hline Nevada & 477,000 & 130,000 & $30.6(25.6-36.1)$ & $30.2(22.3-39.3)$ \\
\hline New Hampshire & 282,000 & 58,000 & $23.0(20.7-25.6)$ & $26.6(21.6-32.3)$ \\
\hline New Jersey & $1,590,000$ & 424,000 & $30.0(27.5-32.6)$ & $33.6(28.9-38.7)$ \\
\hline New Mexico & 386,000 & 110,000 & $32.2(29.3-35.2)$ & $32.7(27.4-38.5)$ \\
\hline New York & $3,629,000$ & 821,000 & $30.9(28.6-33.3)$ & $32.3(27.8-37.2)$ \\
\hline North Carolina & $2,089,000$ & 687,000 & $35.8(33.2-38.6)$ & $34.5(30.3-38.9)$ \\
\hline North Dakota & 134,000 & 21,000 & $19.2(16.3-22.4)$ & $23.4(17.8-30.2)$ \\
\hline Ohio & $2,547,000$ & 695,000 & $30.4(28.1-32.8)$ & $30.1(25.8-34.6)$ \\
\hline Oklahoma & 813,000 & 259,000 & $35.0(32.3-37.9)$ & 36.9 (32.2-41.9) \\
\hline Oregon & 838,000 & 178,000 & $24.3(21.6-27.2)$ & $25.7(21.2-30.8)$ \\
\hline Pennsylvania & $2,937,000$ & 723,000 & $28.1(25.5-30.9)$ & $28.7(23.9-34.0)$ \\
\hline Rhode Island & 226,000 & 59,000 & $29.9(27.1-33.0)$ & $34.7(28.6-41.4)$ \\
\hline South Carolina & $1,105,000$ & 361,000 & $36.1(34.0-38.2)$ & $36.7(32.9-40.7)$ \\
\hline South Dakota & 158,000 & 36,000 & $24.1(20.9-27.6)$ & $27.3(21.4-34.2)$ \\
\hline Tennessee & $1,630,000$ & 481,000 & $34.2(31.1-37.4)$ & $35.3(30.1-40.8)$ \\
\hline Texas & $4,055,000$ & $1,138,000$ & $33.3(30.5-36.3)$ & $32.0(27.5-36.9)$ \\
\hline Utah & 407,000 & 77,000 & $21.2(19.4-23.2)$ & $20.3(17.7-23.2)$ \\
\hline Vermont & 136,000 & 29,000 & $23.2(20.8-25.9)$ & $25.5(21.0-30.7)$ \\
\hline Virginia & $1,513,000$ & 381,000 & $27.5(25.2-29.9)$ & $26.7(23.0-30.7)$ \\
\hline Washington & $1,346,000$ & 282,000 & $23.0(21.3-24.6)$ & $22.7(19.6-26.1)$ \\
\hline West Virginia & 557,000 & 204,000 & $39.8(37.5-42.1)$ & $41.6(37.9-45.3)$ \\
\hline Wisconsin & $1,104,000$ & 232,000 & $24.0(21.3-27.0)$ & $23.7(19.1-28.9)$ \\
\hline Wyoming & 116,000 & 22,000 & $20.7(17.7-24.2)$ & $22.7(17.3-29.3)$ \\
\hline Median (Range)** & & & $28.4(19.2-45.5)$ & $29.7(20.3-46.0)$ \\
\hline Guam & 17,000 & 5,000 & $31.3(24.0-39.6)$ & $27.0(19.8-35.8)$ \\
\hline Puerto Rico & 635,000 & 340,000 & $56.0(52.9-59.0)$ & $58.2(52.1-64.1)$ \\
\hline
\end{tabular}

Abbreviation: $\mathrm{Cl}=$ confidence interval.

* Age standardized to the 2000 U.S. projected population, using three age groups: 18-44, 45-64, and $\geq 65$ years.

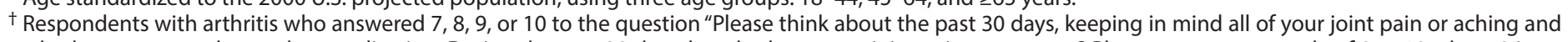

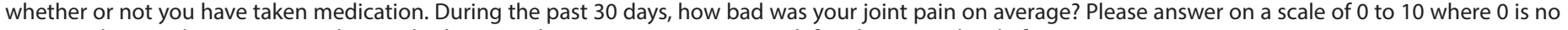
pain or aching and 10 is pain or aching as bad as it can be." Severe joint pain was defined as a pain level of 7-10.

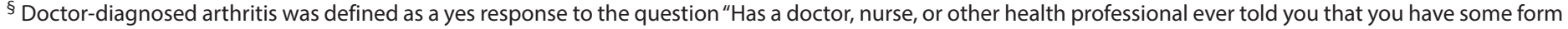
of arthritis, rheumatoid arthritis, gout, lupus, or fibromyalgia?"

१ Estimates with a relative standard error $\geq 30 \%$ or unweighted denominator $<50$ were suppressed as unreliable.

** Median and range were calculated from estimates for the 50 states and the District of Columbia. 
TABLE 13. Unadjusted* and age-standardized ${ }^{\dagger}$ percentages of adults aged $\geq 18$ years with arthritis ${ }^{\S}$ reporting they attended a self-management education course for their arthritis," by selected state - Behavioral Risk Factor Surveillance System, 13 states, ${ }^{* *} 2015$

\begin{tabular}{|c|c|c|c|c|}
\hline State & $\begin{array}{l}\text { No. of respondents } \\
\text { with arthritis }\end{array}$ & $\begin{array}{l}\text { Weighted population with } \\
\text { arthritis and attendance at } \\
\text { self-management education course } \\
\text { (rounded to } 1,000 \mathrm{~s} \text { ) }\end{array}$ & $\begin{array}{l}\text { Unadjusted } \\
\%(95 \% \mathrm{Cl})\end{array}$ & $\begin{array}{c}\text { Age-standardized } \\
\%(95 \% \mathrm{Cl})\end{array}$ \\
\hline California & 2,803 & 818,000 & $15.4(11.5-20.3)$ & $13.6(9.3-19.6)$ \\
\hline Kansas & 7,320 & 53,000 & $11.2(9.9-12.7)$ & $11.9(9.5-14.8)$ \\
\hline Kentucky & 3,565 & 110,000 & $11.5(9.9-13.3)$ & $12.2(9.5-15.5)$ \\
\hline Michigan & 3,224 & 259,000 & $12.2(10.4-14.1)$ & $12.5(9.3-16.5)$ \\
\hline Minnesota & 4,666 & 116,000 & $14.2(12.9-15.5)$ & $15.3(12.7-18.4)$ \\
\hline Missouri & 2,808 & 157,000 & $13.5(11.7-15.5)$ & $14.5(11.2-18.7)$ \\
\hline Montana & 2,123 & 29,000 & $14.5(12.2-17.0)$ & $19.0(14.4-24.6)$ \\
\hline New York & 3,921 & 323,000 & $10.6(8.7-12.8)$ & $9.1(6.9-11.9)$ \\
\hline Oregon & 1,828 & 130,000 & $17.2(13.8-21.3)$ & $18.1(12.4-25.5)$ \\
\hline Pennsylvania & 2,059 & 294,000 & $11.9(10.0-14.1)$ & $15.1(11.3-20.0)$ \\
\hline Rhode Island & 2,244 & 21,000 & $10.8(9.1-12.8)$ & $10.6(7.7-14.4)$ \\
\hline South Carolina & 4,405 & 126,000 & $12.9(11.4-14.5)$ & $16.5(13.2-20.4)$ \\
\hline Utah & 2,929 & 60,000 & $16.6(13.9-19.8)$ & $18.0(13.5-23.5)$ \\
\hline Median (Range) ${ }^{t+}$ & & & $12.9(10.6-17.2)$ & $14.5(9.1-19.0)$ \\
\hline
\end{tabular}

Abbreviation: $\mathrm{Cl}=$ confidence interval.

* The numerator was the estimated number of adults with arthritis who reported ever having taken an educational course or class to learn to manage their arthritis. The denominator was the estimated number of adults with arthritis.

${ }^{\dagger}$ Age standardized to the 2000 U.S. projected population, using three age groups: $18-44,45-64$, and $\geq 65$ years.

$\S$ Doctor-diagnosed arthritis was defined as a yes response to the question "Has a doctor, nurse, or other health professional ever told you that you have some form of arthritis, rheumatoid arthritis, gout, lupus, or fibromyalgia?"

"Respondents who answered yes to the question "Have you ever taken an educational course or class to teach you how to manage problems related to your arthritis or joint symptoms?"

** States that administered the Behavioral Risk Factor Surveillance System (BRFSS) arthritis management module: California, Kansas, Kentucky, Michigan, Minnesota, Missouri, Montana, New York, Oregon, Pennsylvania, Rhode Island, South Carolina, and Utah.

${ }^{+\dagger}$ Median and range were calculated from estimates for the 13 states that administered the BRFSS arthritis management module. 


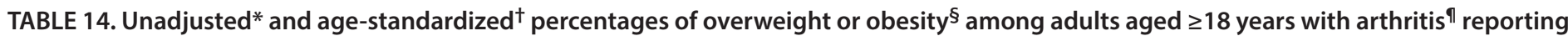
health care provider counseling to lose weight to help with their arthritis or joint symptoms, ${ }^{* *}$ by selected state - Behavioral Risk Factor Surveillance System, 13 states, ${ }^{\text {†+ }} 2015$

\begin{tabular}{|c|c|c|c|c|c|c|}
\hline State & $\begin{array}{c}\text { No. of } \\
\text { respondents } \\
\text { with arthritis }\end{array}$ & $\begin{array}{l}\text { No. of } \\
\text { respondents } \\
\text { who are } \\
\text { overweight or } \\
\text { obese }\end{array}$ & $\begin{array}{l}\text { Weighted population } \\
\text { with arthritis who } \\
\text { are overweight } \\
\text { or obese } \\
\text { (rounded to } 1,000 \text { s) }\end{array}$ & $\begin{array}{l}\text { Weighted population with } \\
\text { arthritis who are } \\
\text { overweight or obese } \\
\text { reporting counseling to lose } \\
\text { weight (rounded to } 1,000 \text { s) }\end{array}$ & $\begin{array}{l}\text { Unadjusted } \\
\%(95 \% \mathrm{CI})\end{array}$ & $\begin{array}{c}\text { Age-standardized } \\
\%^{*}(95 \% \mathrm{Cl})\end{array}$ \\
\hline California & 2,803 & 504 & $5,719,000$ & $1,762,000$ & $48.9(41.5-56.4)$ & $40.1(30.9-50.1)$ \\
\hline Kansas & 7,320 & 2,127 & 536,000 & 133,000 & $41.6(39.0-44.1)$ & 39.9 (35.7-44.3) \\
\hline Kentucky & 3,565 & 2,289 & $1,087,000$ & 339,000 & $48.4(44.9-52.0)$ & $52.7(46.6-58.7)$ \\
\hline Michigan & 3,224 & 1,375 & $2,305,000$ & 734,000 & $48.6(45.3-52.0)$ & $49.4(43.5-55.3)$ \\
\hline Minnesota & 4,666 & 2,885 & 907,000 & 246,000 & $43.0(40.7-45.3)$ & $44.3(39.7-49.0)$ \\
\hline Missouri & 2,808 & 1,751 & $1,372,000$ & 384,000 & $47.7(44.4-51.0)$ & $49.8(43.0-56.6)$ \\
\hline Montana & 2,123 & 1,304 & 216,000 & 50,000 & $39.3(35.6-43.0)$ & $35.1(28.7-42.1)$ \\
\hline New York & 39,21 & 1,112 & $3,629,000$ & $1,118,000$ & $52.9(48.7-57.0)$ & $53.2(45.2-61.1)$ \\
\hline Oregon & 1,828 & 528 & 838,000 & 245,000 & $47.8(42.0-53.7)$ & $47.5(36.7-58.5)$ \\
\hline Pennsylvania & 2,059 & 1,268 & $2,937,000$ & 801,000 & $44.6(41.1-48.2)$ & $42.4(35.7-49.4)$ \\
\hline Rhode Island & 2,244 & 1,271 & 226,000 & 64,000 & $49.9(46.2-53.6)$ & $41.5(34.7-48.6)$ \\
\hline South Carolina & 4,405 & 2,812 & $1,105,000$ & 327,000 & $46.6(44.0-49.2)$ & $47.6(42.9-52.4)$ \\
\hline Utah & 2,929 & 919 & 407,000 & 114,000 & $45.6(41.2-50.2)$ & $44.5(37.6-51.5)$ \\
\hline Median $(\text { Range })^{\S \S}$ & & & & & $47.7(39.3-52.9)$ & $44.5(35.1-53.2)$ \\
\hline
\end{tabular}

Abbreviation: $\mathrm{Cl}$ = confidence interval.

* The numerator was the estimated number of adults with arthritis who reported being told by their doctor to exercise or get physical activity. The denominator was the estimated number of adults with arthritis.

+ Age standardized to the 2000 U.S. projected population, using three age groups: $18-44,45-64$, and $\geq 65$ years.

$\S$ Overweight: body mass index 25.0-29.9; obese: body mass index $\geq 30$; calculated from self-reported height and weight.

" Doctor-diagnosed arthritis was defined as a yes response to the question "Has a doctor, nurse, or other health professional ever told you that you have some form of arthritis, rheumatoid arthritis, gout, lupus, or fibromyalgia?"

** Respondents who were overweight or obese who answered yes to the question "Has a doctor or other health professional ever suggested losing weight to help your arthritis or joint symptoms?"

t+ States that administered the Behavioral Risk Factor Surveillance System (BRFSS) arthritis management module: California, Kansas, Kentucky, Michigan, Minnesota, Missouri, Montana, New York, Oregon, Pennsylvania, Rhode Island, South Carolina, and Utah.

$\S \S$ Median and range were calculated from estimates for the 13 states that administered the BRFSS arthritis management module. 
TABLE 15. Unadjusted* and age-standardized ${ }^{\dagger}$ percentages of adults aged $\geq 18$ years with arthritis ${ }^{\S}$ reporting health care provider counseling for physical activity or exercise, ${ }^{\natural}$ by selected state - Behavioral Risk Factor Surveillance System, 13 states, ${ }^{* *} 2015$

\begin{tabular}{|c|c|c|c|c|}
\hline State & $\begin{array}{l}\text { No. of respondents } \\
\text { with arthritis }\end{array}$ & $\begin{array}{l}\text { Weighted population with } \\
\text { arthritis reporting counseling } \\
\text { for physical activity or } \\
\text { exercise (rounded to } 1,000 \text { s) }\end{array}$ & $\begin{array}{l}\text { Unadjusted } \\
\%(95 \% \mathrm{Cl})\end{array}$ & $\begin{array}{c}\text { Age standardized } \\
\% *(95 \% \mathrm{Cl})\end{array}$ \\
\hline California & 2,803 & $3,022,000$ & $57.0(50.9-62.9)$ & $57.8(48.2-66.9)$ \\
\hline Kansas & 7,320 & 247,000 & $52.6(50.4-54.7)$ & $52.3(48.4-56.1)$ \\
\hline Kentucky & 3,565 & 514,000 & $53.8(50.8-56.8)$ & $53.6(48.3-58.8)$ \\
\hline Michigan & 3,224 & $1,242,000$ & $59.0(56.2-61.7)$ & $61.5(56.5-66.3)$ \\
\hline Minnesota & 4,666 & 462,000 & $57.1(55.2-59.0)$ & $58.1(54.4-61.7)$ \\
\hline Missouri & 2,808 & 668,000 & $57.8(54.9-60.6)$ & $57.0(51.1-62.8)$ \\
\hline Montana & 2,123 & 112,000 & $55.5(52.3-58.6)$ & $57.8(52.0-63.4)$ \\
\hline New York & 3,921 & $1,925,000$ & $63.4(60.1-66.5)$ & $61.9(55.1-68.2)$ \\
\hline Oregon & 1,828 & 445,000 & $59.6(54.6-64.4)$ & $61.7(52.9-69.9)$ \\
\hline Pennsylvania & 2,059 & $1,439,000$ & $58.5(55.4-61.4)$ & $59.8(54.0-65.4)$ \\
\hline Rhode Island & 2,244 & 115,000 & $60.9(57.8-63.8)$ & $59.6(53.0-65.8)$ \\
\hline South Carolina & 4,405 & 586,000 & $60.4(58.3-62.6)$ & $61.2(57.1-65.1)$ \\
\hline Utah & 2,929 & 207,000 & $58.2(54.4-61.8)$ & $58.5(52.5-64.3)$ \\
\hline Median (Range) ${ }^{t+}$ & & & $58.2(52.6-63.4)$ & $58.5(52.3-61.9)$ \\
\hline
\end{tabular}

Abbreviation: $\mathrm{Cl}$ = confidence interval.

* The numerator was the estimated number of adults with arthritis who reported being told by their health care provider to exercise or get physical activity. The denominator was the estimated number of adults with arthritis.

${ }^{\dagger}$ Age standardized to the 2000 U.S. projected population, using three age groups: $18-44,45-64$, and $\geq 65$ years.

$\S$ Doctor-diagnosed arthritis was defined as a yes response to the question "Has a doctor, nurse, or other health professional ever told you that you have some form of arthritis, rheumatoid arthritis, gout, lupus, or fibromyalgia?"

" Respondents who answered yes to the question "Has a doctor or other health professional ever suggested physical activity or exercise to help your arthritis or joint symptoms?"

** States that administered the Behavioral Risk Factor Surveillance System (BRFSS) arthritis management module: California, Kansas, Kentucky, Michigan, Minnesota, Missouri, Montana, New York, Oregon, Pennsylvania, Rhode Island, South Carolina, and Utah.

${ }^{+\dagger}$ Median and range were calculated from estimates for the 13 states that administered the BRFSS arthritis management module. 
TABLE 16. Estimates of adults aged $\geq 18$ years with arthritis and age-standardized* percentages of arthritis health-related characteristics among adults with arthritis, ${ }^{\dagger}$ by quartile ${ }^{\S}$ of state-level prevalence of arthritis - Behavioral Risk Factor Surveillance System, United States, 2015

\begin{tabular}{|c|c|c|c|c|c|}
\hline Estimate/Characteristic & $\begin{array}{c}\text { Q1 }(17.2 \%-21.5 \%) \\
\%(95 \% \mathrm{Cl})\end{array}$ & $\begin{array}{c}\text { Q2 (21.5\%-22.7\%) } \\
\%(95 \% \mathrm{Cl})\end{array}$ & $\begin{array}{c}\text { Q3 (23.0\%-25.4\%) } \\
\%(95 \% \mathrm{Cl})\end{array}$ & $\begin{array}{l}\text { Q4 (25.7\%-33.6\%) } \\
\quad \%(95 \% \mathrm{Cl})\end{array}$ & p-trend? \\
\hline No. of respondents with arthritis & 36,278 & 43,596 & 29,347 & 36,929 & - \\
\hline Weighted population with arthritis & $21,702,000$ & $12,741,000$ & $10,866,000$ & $15,694,000$ & - \\
\hline Arthritis-attributable activity limitations & $48.7(46.7-50.6)$ & $47.8(46.1-49.5)$ & $49.1(47.1-51.2)$ & $52.9(51.3-54.4)$ & $<0.001$ \\
\hline Arthritis-attributable severe joint pain & $31.3(29.5-33.2)$ & $26.6(25.2-28.1)$ & $29.5(27.7-31.5)$ & $35.4(33.9-36.8)$ & $<0.001$ \\
\hline $\begin{array}{l}\text { Arthritis-attributable social participation } \\
\text { restriction }\end{array}$ & $20.1(18.5-21.8)$ & $17.4(16.2-18.6)$ & $20.5(18.9-22.1)$ & $23.7(22.5-25.1)$ & $<0.001$ \\
\hline $\begin{array}{l}\geq 14 \text { physically unhealthy days during } \\
\text { past } 30 \text { days }\end{array}$ & $27.3(25.6-29.0)$ & $26.2(24.7-27.7)$ & $27.0(25.3-28.8)$ & $30.2(28.9-31.5)$ & $<0.006$ \\
\hline $\begin{array}{l}\geq 14 \text { mentally unhealthy days during } \\
\text { past } 30 \text { days }\end{array}$ & $22.6(21.0-24.3)$ & $22.1(20.7-23.5)$ & $24.0(22.2-25.9)$ & $25.7(24.4-27.1)$ & 0.001 \\
\hline Obesity & $37.4(35.6-39.3)$ & $39.5(37.8-41.2)$ & $40.3(38.4-42.4)$ & $45.0(43.6-46.5)$ & $<0.001$ \\
\hline Leisure-time physical inactivity & $33.8(32.0-35.8)$ & $31.4(29.8-33.0)$ & $35.0(33.0-37.0)$ & $38.4(37.0-39.9)$ & $<0.001$ \\
\hline Leisure-time walking & $48.2(46.3-50.1)$ & $49.5(47.8-51.2)$ & $48.0(46.0-50.1)$ & $45.1(43.6-46.6)$ & 0.001 \\
\hline
\end{tabular}

Abbreviations: $\mathrm{Cl}=$ confidence interval; $\mathrm{Q}=$ quartile.

* Age standardized to the 2000 U.S. projected population, using three age groups: $18-44,45-64$, and $\geq 65$ years.

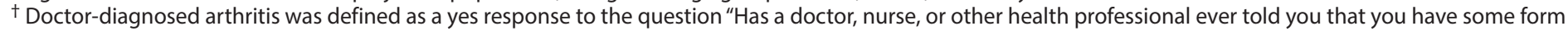
of arthritis, rheumatoid arthritis, gout, lupus, or fibromyalgia?"

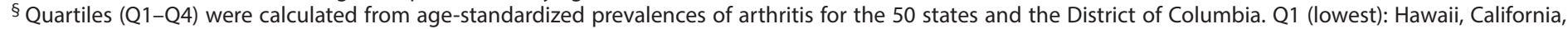

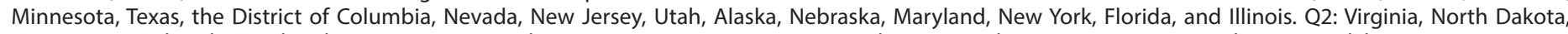

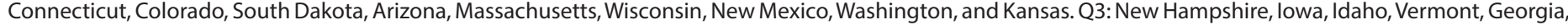

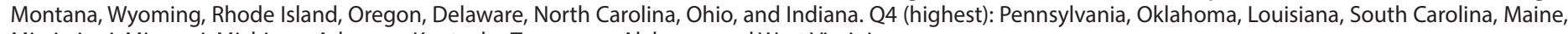
Mississippi, Missouri, Michigan, Arkansas, Kentucky, Tennessee, Alabama, and West Virginia.

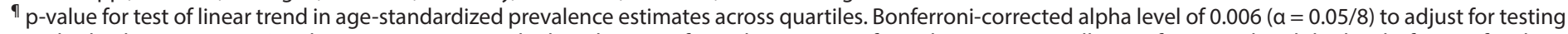

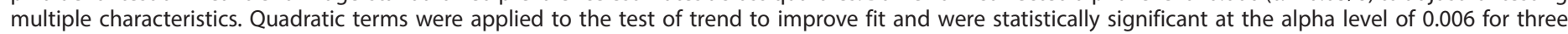
characteristics (arthritis-attributable severe joint pain, arthritis-attributable social participation restriction, and leisure-time physical inactivity). 

The Morbidity and Mortality Weekly Report (MMWR) Series is prepared by the Centers for Disease Control and Prevention (CDC) and is available free of charge in electronic format. To receive an electronic copy each week, visit $M M W R$ 's free subscription page at https://www.cdc.gov/mmwr $/ \mathrm{mmwrsubscribe.html}$. Paper copy subscriptions are available through the Superintendent of Documents, U.S. Government Printing Office, Washington, DC 20402; telephone 202-512-1800.

Readers who have difficulty accessing this PDF file may access the HTML file at https://www.cdc.gov/mmwr/volumes/67/ss/ss6704a1.htm?s_ cid=ss6704a1_w. Address all inquiries about the $M M W R$ Series, including material to be considered for publication, to Executive Editor, $M M W R$ Series, Mailstop E-90, CDC, 1600 Clifton Rd., N.E., Atlanta, GA 30329-4027 or to mmwrq@cdc.gov.

All material in the MMWR Series is in the public domain and may be used and reprinted without permission; citation as to source, however, is appreciated.

Use of trade names and commercial sources is for identification only and does not imply endorsement by the U.S. Department of Health and Human Services.

References to non-CDC sites on the Internet are provided as a service to $M M W R$ readers and do not constitute or imply endorsement of these organizations or their programs by CDC or the U.S. Department of Health and Human Services. CDC is not responsible for the content of these sites. URL addresses listed in $M M W R$ were current as of the date of publication.

ISSN: 1546-0738 (Print) 